SJ Quinney College of Law, University of Utah

Utah Law Digital Commons

4-2021

The Regulatory Shifting Baseline Syndrome: Public Law as Cultural Memory

Robin Kundis Craig

Follow this and additional works at: https://dc.law.utah.edu/scholarship

Part of the Public Law and Legal Theory Commons 


\title{
The Regulatory SHIFTINg BASELINE SYNDROME: Public LaW as Cultural Memory
}

\author{
Robin Kundis Craig*
}

\begin{abstract}
In 2013, the U.S. Supreme Court declared unconstitutional the Voting Rights Act's preclearance requirements for six states'voting laws, and many of those states almost immediately enacted new voting restrictions, that disparately affected citizens of color. In the 1980s and 1990s, Congress deregulated financial markets, including dismantling protections that had been in place since the New Deal, allowing firms to introduce new forms of derivatives - and systemic risk-into the economy, leading to 2008's housing crisis. In the early 21st century, state legislatures increasingly enacted exemptions from state vaccination requirements that allowed parents to skip their children's vaccinations, setting the stage for resurgences of measles in 2015 and 2019. Since at least 2001, courts, federal agencies, citizens, and NGOs have focused on the Clean Water Act's alleged intrusions into state sovereignty and private property rights in the context of "dredge and fill" permits, undermining the Act's continuing ability to improve the overall quality of the nation's waterbodies.

All of these seemingly unrelated legal phenomena derive, at least in part, from the regulatory shifting baseline syndrome.

In 1995, Dr. Daniel Pauly described the "shifting baseline syndrome" and its problems for fisheries management. Pauly posited that each
\end{abstract}

\footnotetext{
* Through June 30, 2021: James I. Farr Presidential Endowed Professor of Law \& University Distinguished Professor, University of Utah S.J. Quinney College of Law, Salt Lake City, UT. From January 1 through June 30, 2021: Visiting Professor of Law, USC Gould School of Law, Los Angeles, CA. From July 1, 2021: Chaired Professor of Law, USC Gould School of Law, Los Angeles, CA. Research for this article received generous support from the Albert and Elaine Borchard Fund for Faculty Excellence at the University of Utah S.J. Quinney College of Law. I would like to thank my Utah Quinney Fellow Emma Tanner for her wide-ranging research in support of this article and the many faculty who provided helpful suggestions for this article throughout its development at the Law Faculty Works-in-Progress Workshop at the 2019 ABA Section on Environment, Energy, and Resources Annual Fall Conference; the Environmental, Natural Resources, and Energy Law Works-in-Progress session at the 2020 AALS Annual Meeting; the October 2020 Vermont Colloquium on Environmental Scholarship; the U.C. Davis School of Law Faculty Workshop in February 2021; Utah S.J. Quinney College of Law Faculty Workshop in March 2021; the Spring 2021 Online Workshop for Environmental Scholarship in March 2021; and the USC Gould School of Law Faculty Workshop in March 2021. Nevertheless, all arguments in this article remain my responsibility. I may be reached at rcraig@law.usc.edu.
} 
generation of fishers and fisheries managers forgets what the ocean and its fisheries used to be, instead taking the current state-demonstrably impoverished from a historical perspective-as normal. The forgetting of history, in other words, makes opaque what the goals of fisheries regulation should be, or even could be.

This Article brings the shifting baseline concept into public law, identifying for the first time a regulatory shifting baseline syndrome that can undermine the law's ability to protect society at large. This syndrome arises when a long-existing public legal regime so successfully eliminates a societal problem that citizens, politicians, and lawmakers forget that the regime is in fact still working to keep that problem at bay. The syndrome is especially problematic in areas of public law where curbing human behavioral tendencies remains an important component of protecting public goods, benefits, or amenities, regardless of how secure the relevant public commons now appears. Acknowledging the syndrome thus challenges would-be law reformers to ask whether we should recover the historical lessons about ourselves and our collective abilities to harm society at large before dismantling the legal protections prior generations felt compelled to enact.

\section{TABLE OF CONTENTS}

\section{INTRODUCTION}

I. THE SHIFTING BASELINE SYNDROME IN FiSHERIES AND OTHER ECOlOGiCAl MANAGEMENT . . . . . . . . . . . . 13
A. Daniel Pauly's Insight: The Origin of the Shifting Baseline Syndrome . . . . . . . . . . . . . . . . 14

B. Use of the Shifting Baseline Syndrome in Fisheries Management . 15

C. The Shifting Baseline Syndrome in Ecology, Conservation, and Ecological Management . . . . . . . . . . . . 16

D. From Ecology to Regulatory Regimes: The Regulatory Shifting Baseline Syndrome

II. RECONCEPTUALIZING THE 2008 ECONOMiC CRASH AS THE PRODUCT OF A REGUlatory SHIFTING BASELINE SYNDROME . . . . . . .20

III. RECONCEPTUALIZING THE CONTEMPORARY ANTI-VAXXER MOVEMENT AS A REgUlatory SHIfTING BASELINE SYNDROME . . . . . . 26 A. Vaccination and the Public Health Commons . . . . . $\quad$. 27 B. Vaccination Regulation in the U.S. into the Late 20th Century . $\quad 29$ 1. Federal Vaccination Programs . . . . . . . . . $\quad .30$

2. State Vaccination Requirements for School Attendance . . . 30 
a. State Authority to Require Vaccines . . . . . . . 30

b. The Eventual Universality of School Vaccination Mandates . 32

C. Initial Signals of a Regulatory Shifting Baseline Syndrome: Vaccine Lawsuits, the Childhood Vaccine Injury Act of 1986, and State Vaccine Exemptions . . . . . . . . . . . . . 33

1. Vaccine Litigation and the National Childhood Vaccine Injury Act of 1986

2. Exemptions from State Vaccination Mandates . . . . . 35

a. Increasing Numbers of State Exemptions from School Vaccination Requirements . . . . . . . . . . 35

b. Personal Philosophical Exemptions from Vaccine Requirements . . . . . . . . . . . . . 36

c. Religious Exemptions from Vaccine Requirements . . . 38

d. Correlations Between Exemptions and Reduced Vaccination Rates . . . . . . . . . . . . . . . 41

D. The Regulatory Shifting Baseline Syndrome and Anti-Vaxxers . $\quad 42$

1. Anti-Vaxxers in the United States . . . . . . . . . 42

2. Anti-Vaxxers and Measles . . . . . . . . . . . . 43

E. The Resumption of Vaccine Requirements, with a Note on the Coronavirus Pandemic . . . . . . . . . . . . 44

1. The Federal Government's Response to Measles Resurgence . 45

2. The States' Responses to Measles Resurgence . . . . . 45

3. Coronavirus Vaccines and the Anti-Vaxxers . . . . . . . 47

IV. RECONCEPTUALIZING THE "WATERS OF THE UNITED STATES" CONTROVERSY AS A REgUlatory SHIFTING BASELINE SYNDROME . . . . . . . 48

A. U.S. Waterways: From Open Access Resource to Regulated Commons . . . . . . . . . . . . . . . . . 50

B. Structuring the Clean Water Act's Permit Programs . . . . $\quad 53$

C. From NPDES to Section 404: The Consequences of Shifting Regulatory Attention . . . . . . . . . . . . . . 55

1. Overview of the U.S. Supreme Court's Clean Water Act Decisions . . . . . . . . . . . . . . . 55

2. The Supreme Court's View of the NPDES Permit Program: Protect the Public Commons . . . . . . . . . . . . 57

3. The Supreme Court's View of "Waters of the United States" through the Section 404 Permit Program: Protect State Prerogatives and Private Property Rights

D. What Lessons Does the Regulatory Shifting Baseline Syndrome Offer for the Clean Water Act? . . . . . . . . . . . 69

V. CONCLUSION . . . . . . . . . . . . . . . . . . 
And you, of tender years,

Can't know the fears,

That your elders grew by. -- Crosby, Stills, Nash \& Young, "Teach Your Children"

Those who cannot remember the past are condemned to repeat it. Studying history is necessary to avoid repeating past mistakes.

-- George Santayana

\section{INTRODUCTION}

In June 2013, in Shelby County v. Holder, a five-Justice majority of the U.S. Supreme Court rejected the historical underpinnings of the Voting Rights Act of 1965, holding unconstitutional the Act's mandate that some states (and only some states) seek federal permission before enacting voting laws ("preclearance requirements"). ${ }^{1}$ According to the Court majority, times have changed:

There is no denying ... that the conditions that originally justified these measures no longer characterize voting in the covered jurisdictions. By 2009, "the racial gap in voter registration and turnout [was] lower in the States originally covered by $\S 5$ than it [was] nationwide." Since that time, Census Bureau data indicate that African-American voter turnout has come to exceed white voter turnout in five of the six States originally covered by $\S 5$, with a gap in the sixth State of less than one half of one percent. ${ }^{2}$

The issue for the Court was not whether voting discrimination still existed; the majority admitted that it did. ${ }^{3}$ Rather, "The question is whether the Act's extraordinary measures, including its disparate treatment of the States, continue to satisfy constitutional requirements. As we put it a short time ago, 'the Act imposes current burdens and must be justified by current needs." 4

The Shelby County Court had decided to tussle with the regulatory shifting baseline syndrome. The Justices' split, moreover, underscores the importance of public regulatory regimes as cultural memory institutions.

In 1995, Dr. Daniel Pauly described the "shifting baseline syndrome" and the

\footnotetext{
${ }^{1}$ Shelby County v. Holder, 570 U.S. 529, 556-57 (2013) (referencing Voting Rights Act of 1965, $\S \S 4$, 5, formerly 42 U.S.C. $\S \S 1973 b, 1973$ c, now 52 U.S.C. $\S \S 10303,10304)$.

${ }_{2}^{2}$ Id. at 535 (quoting Northwest Austin Municipal Util. Dist. No. One v. Holder, 557 U.S. 193, $203-$ 204 (2009)).

${ }^{3} I d$. at 536 .

${ }^{4}$ Id. (quoting Northwest Austin, 557 U.S., at 203).
} 
problems it causes for fisheries management. ${ }^{5}$ Pauly argued that each generation of fishers and fisheries managers forgets what the ocean and its fisheries used to sustain, instead taking the current abundance and size of desired fish-however demonstrably impoverished those might be from a historical perspective - as normal. ${ }^{6}$ As a result, fisheries management, laws, and policies never seek to restore fisheries and marine ecosystems to true health, but instead accept and adjust to progressively worsening ecological conditions. ${ }^{7}$ The forgetting of history, in other words, makes opaque what the goals of regulation should be, or even could be. In fisheries regulation and other forms of species and ecosystem management, therefore, reconstructing historical ecological conditions has become the means of correcting the shifting baseline syndrome. ${ }^{8}$

This Article moves the shifting baseline syndrome into public law, ${ }^{9}$ arguing that successful regulatory regimes can actually cause a shifting baseline syndrome- the regulatory shifting baseline syndrome. This syndrome arises when the laws created to correct a particular societal problem are so successful that, after some time passes, citizens, politicians, courts, administrative agencies, and legislatures forget that that regulatory regime is in fact still functioning. The syndrome thus distorts public estimation of the regime's continuing existential value, potentially inducing courts, legislatures, and agencies to weaken, dismantle, or eliminate it.

Given its society-wide function, public law ought to serve as a form of cultural memory or memory institution, a record of why a community has legally protected itself in the ways that it has. "Memory institutions are social entities that select, document, contextualize, preserve, index, and thus canonize elements of humanity's culture, historical narratives, [and] individual[] and collective

\footnotetext{
${ }^{5}$ Daniel Pauly, Anecdotes and The Shifting Baseline Syndrome in Fisheries, 10 TrEndS IN ECOLOGY \& EVOLUTION 430, 430 (1995).

${ }^{6} I d$.

${ }^{7} \mathrm{Id}$.

${ }^{8}$ See discussion infra Part I.

9 "Public law," for purposes of this discussion, refers to the statutes, regulations, and policies that both regulate government itself and operate to protect society as a whole from problems that arise at scales too large to deal with effectively through private law mechanisms, such as contracting, insurance, or tort liability. Scholars generally distinguish "public law" from "private law" either on the basis that public law involves and regulates the government itself, see, e.g., David Sloss, Polymorphic Public Law Litigation: The Forgotten History of Nineteenth Century Public Law Litigation, 71 WASH. \& LeE L. Rev. 1757, 1767-68 (2014); Ryan J. Cassidy, Prefatory Remarks: Administrative Law and the First Annual Survey, 5 WIDENER J. PUB. L. 617, 621-22 (1996), or on the basis of the law's subject matter. See, e.g., Philip J. McConnaughay, Reviving the "Public Law Taboo" in International Conflict of Laws, 35 STAN. J. InT'L L. 255, 261, 300-304 (1999) (noting that "private law and public law are defined according to the categories or types of law traditionally within each: private law traditionally includes contracts, torts, property, and family law, while public law traditionally includes antitrust, securities, exchange controls, and most economic regulation"). This Article embraces both inflections of "public law" but relies more heavily on the latter, extending McConnaughay's emphasis on "public law's focus on the public interest and preventing public harm," $i d$. at 302, to public health law and environmental and natural resources law.
} 
memories." 10 Traditional and paradigmatic memory institutions include archives, museums, and libraries; more contemporary additions include the various "networked memory institutions" of the internet and social media. ${ }^{11}$ However, statutes and regulatory regimes, together with the histories of their creation, are also memory institutions. ${ }^{12}$

Unfortunately, the status of public legal regimes as memory institutions is underappreciated, particularly within the law itself. ${ }^{13}$ To be sure, examination of statutory purpose remains a bedrock touchstone of statutory interpretation, and courts continue to examine statutory history ${ }^{14}$ and even legislative history ${ }^{15}$ in the process. However, the process of statutory construction occurs within the regulatory regime itself and assumes that regime's continued legitimacy. The cultural memory at issue in this Article, in contrast, operates at a higher scale, informing not (or not just) what the particular instruments (laws, regulations) mean but rather their continuing value to society. Indeed, the very existence of public laws on a particular subject should remind citizens, politicians, judges, and legislators that there was in fact a historical problem that might recur if the correcting regulatory regime does not remain in place.

${ }^{10}$ Guy Pessach, [Networked] Memory Institutions: Social Remembering, Privatization and Its Discontents, 26 CARDOZO ARTS \& ENT. L.J. 71, 73 (2008) (citing ARCHIVES, DocUMENTS AND InSTITUTIONS OF SOCIAL MEMORY: EsSAYS FROM THE SAWYER SEMINAR (Francis X. Blouin, Jr. \& William G. Rosenberg eds., 2006); REPRESEnTING THE NATION: A READER-HistoriEs, HERITAGE AND Museums (David Boswell \& Jessica Evans eds., 1999).

${ }^{11} I d$.

12 Notably, the European Union is dealing with the opposite problem in the form of so-called "memory laws," which seek to reify a particular interpretation or perspective on history. Thus, "“Memory laws' enshrine state-approved interpretations of crucial historical events and promote certain narratives about the past, by banning, for example, the propagation of totalitarian ideologies or criminalising expressions which deny, grossly minimize, approve, or justify acts constituting genocide or crimes against humanity, as defined by international law." Council of Europe, 'Memory Laws' and Freedom of Expression 1 (July 2018), available at https://rm.coe.int/factsheet-onmemory-laws-july2018-docx/16808c1690. However, the use of law to actively construct cultural memory, as Europe justly worries about, is a different enterprise than the one advocated in this Article: the recognition that statutes and regulations created to address public problems constitute contextually situated records of cultural memory.

${ }^{13}$ In contrast, historians often find the laws of earlier times valuable resources in reconstructing historical cultural norms or in establishing the bases of later reform and evolution. E.g., Michael M. Sheehan, Marriage Theory and Practice in the Conciliar Legislation and Diocensan Statutes of Medieval England, 40 MEDIEVAL STUDIEs 408, 408-460 (1978).

14 [Anita S. Krishnakumar, Statutory History (DRAFT 2021)]

${ }^{15}$ E.g., County of Maui, Haw., v. Hawaii Wildlife Fund, --- U.S.---, 140 S. Ct. 1462, 1468-69, 147172, 1476 (2020) (emphasizing Congress's purposes in interpreting the Clean Water Act and including an examination of legislative history); Gundy v. United States, --- U.S. ---, 139 S. Ct. 2116, 2126 (2019) (noting that "beyond context and structure, the Court often looks to 'history [and] purpose' to divine the meaning of language" (quoting Maracich v. Spears, 570 U.S. 48, 76 (2013) (internal quotation marks omitted))); Environmental Defense v. Duke Energy Corp., 549 U.S. 561, 576 (2007) (relying on legislative history); McCreary County, Ky. v. American Civil Liberties Union of Ky., 545 U.S. 844, 861-63 (2005) (discussing the importance of legislative purpose to statutory interpretation). 
In the 21st century, acknowledging the cultural memory embedded in public law serves two different governance goals, particularly when those regulatory regimes have existed for a decade or longer. First, as a memory institution, the laws and regulations at issue are reminders of how their drafters understood the world and the problem at hand, allowing would-be reformers to assess whether those understandings remain objectively valid. As one contemporary example, I and others have argued extensively that the Anthropocene and the increasing impacts of climate change demand a re-evaluation and replacement of regulatory regimes that assume the stationarity of ecological and social-ecological systems, ${ }^{16}$ including new approaches to climate change adaptation. ${ }^{17}$ The regimes in need of significant amendment to acknowledge these evolved scientific understandings include most of the natural resources, public lands, and environmental statutes adopted throughout the 20th century. ${ }^{18}$ The crucial cultural memory embedded in these public laws is the Balance of Nature model of ecosystems prevalent in scientific discourse at the time Congress and state legislatures adopted them. ${ }^{19}$ Recovering that cultural memory illuminates the facts both that our understanding of how complex systems behave has changed significantly since the 1970s, undermining

${ }^{16}$ See generally, e.g., Karrigan Börk, Guest Species: Rethinking Our Approach to Biodiversity in the Anthropocene, 2018 UtAH L. ReV. 169; MELIndA HARM BENSON \& RoBIn Kundis CRAig, ThE END OF SUSTAINABILITY: RESILIENCE AND THE FUTURE OF ENVIRONMENTAL GOVERNANCE IN THE ANTHRopocene (Kansas Univ. Press, 2017); Kalyani Robbins, The Biodiversity Paradigm Shift: Adapting the Endangered Species Act to Climate Change, 27 FORDHAM ENVTL. L. REV. 57 (2015); Lance H. Gunderson, Ahjond Garmestani, Keith W. Rizzardi, J.B. Ruhl, \& Alfred Light, Escaping a Rigidity Trap: Governance and Adaptive Capacity to Climate Change in the Everglades Social Ecological System, 51 IDAHO L. REV. 127 (2014) RoBIn Kundis CRAIG, COMPARATIVE OCEAN Governance: Place-BASed Protections in an Era of Climate Change (Edward Elgar, 2012); Victor B. Flatt, Adapting Laws to a Changing World: A Systemic Approach to Climate Change Adaptation, 64 FLA. L. REV. 269 (2012); Robin Kundis Craig, “Stationarity Is Dead”-Long Live Transformation: Five Principles for Climate Change Adaptation Law, 34 HARV. ENVTL. L. REV. 9 (2010); Alejandro E. Camacho, Assisted Migration: Redefining Nature and Natural Resource Law under Climate Change, 27 YALE J. REgulation 171 (2010); J.B. Ruhl, Climate Change Adaptation and the Structural Transformation of Environmental Law, 40 ENVTL. L. 363 (2010); Robert L. Glicksman, Ecosystem Resilience to Disruptions Linked to Global Climate Change: An Adaptive Approach to Federal Land Management, 87 NeB. L. REV. 833 (2009); J.B. Ruhl, Climate Change and the Endangered Species Act: Building Bridges to the No-Analog Future, 88 B.U. L. REV. 1 (2008).

${ }^{17}$ J.B. Ruhl \& Robin Kundis Craig, $4^{\circ} \mathrm{C}$ (forthcoming 2022).

18 Alejandro E. Camacho \& Robert L. Glicksman, Legal Adaptive Capacity: How Program Goals and Processes Shape Federal Land Adaptation to Climate Change, 87 U. Colo. L. REV. 711, 743806 (2016) (assessing the federal public lands statutes); CRAIG, supra note 16, at 47-65, 91-169 (assessing current legal approaches to marine protected areas); Craig, Stationarity, supra note 16, at 31-40 (assessing pollution control and natural resources statutes); Camacho, Assisted Migration, supra note 16, at 188-210 (assessing species-related and public lands statutes); Ruhl, Structural Transformation, supra note 16, at 391-433 (assessing a broad swath of environmental and natural resources statutes).

${ }^{19}$ Melinda H. Benson, New Materialism: An Ontology for the Anthropocene, 59 NATURAL RES. J. 251, 261 (2019); BENSON \& CRAIG, supra note 16, at 31, 57, 165-66; Craig, Stationarity, supra note 16 , at 32 . 
these statutes' regulatory premises,$^{20}$ and that climate change is accelerating systemic change, undermining these statutes' continuing abilities to function productively. ${ }^{21}$ In other words, acknowledging this first cultural memory function of law helps law- and policymakers to better evaluate when legal regimes do, in fact, need to change.

This Article, however, explores the second governance function served by acknowledging that public law is a form of cultural memory: improved evaluation of whether apparently outdated legal regimes really should remain in place. Specifically, it posits that when legal regimes exist to curb human impulses and behaviors that have been demonstrated to cumulatively damage society as a whole, those regimes serve as important reminders that removal of existing restraints is likely to re-create old problems. Thus, even in the environmental context, an evolved understanding of system dynamics and climate change impacts does not change the fact that pollution control regimes - that is, restraints on historically demonstrated human tendencies to contaminate commons resources (air, rivers, lakes, land, the ocean) with toxics and other damaging pollutants - remain critical protectors of human health and environmental quality in the 21 st century. ${ }^{22}$ Failure to heed these reminders, in contrast, allows the regulatory regime to fall victim to the regulatory shifting baseline syndrome.

Shelby County provides a significant example. Contrary to some characterizations, ${ }^{23}$ the Supreme Court majority did not forget its history. It acknowledged, for example, why Congress had singled out certain states for special treatment under the Voting Rights Act: "In the 1890s, Alabama, Georgia, Louisiana, Mississippi, North Carolina, South Carolina, and Virginia, began to enact literacy tests for voter registration and to employ other methods designed to prevent African-Americans from voting," and as courts struck down these measures, "States came up with new ways to discriminate," effectively preventing registration of black voters. ${ }^{24}$ Instead, the majority concluded that the Act's distinctions among states based on historic practices had served their purposesspecifically, that the states whose voting laws were still subject to federal approval had come into line with, or even improved upon, the rest of the country in terms of black voter registration. ${ }^{25}$ In the majority's view, "things have changed dramatically." 26 The Act had done- emphasis on the past tense-its job, ${ }^{27}$ and the

\footnotetext{
${ }^{20}$ Benson \& Craig, supra note 16, at 56-70; Craig, Stationarity, supra note 16, at 39-40; Camacho, Assisted Migration, supra note 16, at 179-88.

${ }^{21}$ Craig, Stationarity, supra note 16, at 46-48; Camacho, Assisted Migration, supra note 16, at 188210; Ruhl, Structural Transformation, supra note 16, at 391-433; Glicksman, supra note 16, at 83951.

${ }^{22}$ Craig, Stationarity, supra note 16, at 45-46.

${ }^{23}$ E.g., Joel Heller, Shelby County and the End of History, 44 U. MemPHIS L. Rev. 357, 357-59, 385 (2013).

${ }^{24}$ Shelby County, 570 U.S. at 536 (citing South Carolina v. Katzenbach, 383 U.S. 301, 310 (1966)).

${ }^{25} \mathrm{Id}$. at $547-49$.

${ }^{26} \mathrm{Id}$. at 547.

${ }^{27}$ Specifically, according to the Court:
} 
objective regulatory baseline had, according to the majority, moved in constitutionally significant ways. ${ }^{28}$ Problem solved.

In contrast, the dissenters (and, in their view, Congress) appreciated the fact that the Voter Rights Act's preclearance requirements were still doing their job, "facilitat[ing] completion of the impressive gains thus far made" and, hinting at the human impulse problem, "guard[ing] against backsliding." 29 The aftermath of the decision supports their conclusion that the most important regulatory baseline at issue, a state impulse to discriminate. had not, in fact, moved significantly - that is, in the terms of this Article, that the majority Justices reached their constitutional

Coverage today is based on decades-old data and eradicated practices. The formula captures States by reference to literacy tests and low voter registration and turnout in the 1960 s and early 1970s. But such tests have been banned nationwide for over 40 years. And voter registration and turnout numbers in the covered States have risen dramatically in the years since. Racial disparity in those numbers was compelling evidence justifying the preclearance remedy and the coverage formula. There is no longer such a disparity.

In 1965, the States could be divided into two groups: those with a recent history of voting tests and low voter registration and turnout, and those without those characteristics. Congress based its coverage formula on that distinction. Today the Nation is no longer divided along those lines, yet the Voting Rights Act continues to treat it as if it were.

Id. at 551. See also K. Sabeel Rahman, Domination, Democracy, and Constitutional Political Economy in the New Gilded Age: Toward a Fourth Wave of Legal Realism?, 94 TEx. L. REv. 1329, 1335 (2016) ("The Court's dismantling of the Voting Rights Act in Shelby County can be understood as an argument that underlying structural political inequalities that may have justified preclearance are no longer present, and thus ordinary political competition, like market competition, is sufficient to ensure freedom of choice and basic political equality.").

${ }^{28}$ Other scholars have also explicitly characterized the Shelby County majority's opinion as reflecting the Justice's perception of an objectively shifted baseline. See Diane S. Sykes, Minimalism and Its Limits, 2015 CATO Supreme CT. ReV. 17, 32 (noting that "the Court had transparently signaled its discomfort with the coverage formula, which was based on a decades-old baseline that did not reflect changes in voting and discriminatory election practices when Congress reauthorized the Act in 2006.").

${ }^{29}$ Shelby County, 570 U.S. at 559-60 (Ginsburg, J., dissenting). As Joel Heller has more extensively described the survival of this impulse in areas still suffering from the burdensome memory of past discrimination:

An awareness of the long history of voting discrimination on account of race in a jurisdiction may affect the attitudes of present-day policymakers towards race and the right to vote, and thus may influence the types of voting policies that they enact. One possibility is that local or state officials charged with setting voting policies and election procedures will ignore any burden that a policy has on minority voters as simply a natural or unavoidable phenomenon. Centuries of precedent exist for inequality in this area of civic life, and these policymakers know that their not-too-distant predecessors in office enacted and administered such policies with a large degree of indifference, or even support, in their communities.

Heller, supra note 23 , at $385-86$. 
conclusion based on the distorting effects of the regulatory shifting baseline syndrome. The Brennan Center for Justice notes that "[w]ithin 24 hours of the ruling, Texas announced that it would implement a strict photo ID law. Two other states, Mississippi and Alabama, also began to enforce photo ID laws that had previously been barred because of federal preclearance." 30 In a 2018 report, the Center further concluded that "the Supreme Court's 2013 Shelby County v. Holder ruling, which neutered the strongest legal protection against voting discrimination, changed the landscape. A flood of new barriers to voting that would have otherwise been blocked were implemented at once, and newly unfettered legislatures were incentivized to press forward with additional restrictions." 31

Importantly, the need to invoke the cultural memory function of public laws varies by regulatory context. Long-existing regulatory regimes that seem equally incorporated into societal norms nevertheless differentially fall victim to generational amnesia regarding their continuing efficacy. For example, despite their 80-year existence, the protections afforded children through child labor laws remain socially and politically salient. Until the early part of the 20th century, most children in working class families worked long hours, often under dangerous conditions, and from very young ages. ${ }^{32}$ Congress began to intervene as early as

30 The Effects of Shelby County v. Holder, Brennan Center for Justice (Aug. 6, 2018), https://www.brennancenter.org/our-work/policy-solutions/effects-shelby-county-v-holder.

${ }^{31}$ Wendy Weise \& Max Feldman, Brennan Center for Justice, NYU School of Law, The State of Voting 2018, at 5 (2018) (emphasis added), available at https://www.brennancenter.org/sites/default/files/2019-08/Report State of Voting 2018.pdf. The fact that, by 2018 , a total of 23 states had enacted more restrictive voting laws that disparately impacted people of color and other vulnerable populations arguably suggests that federal preclearance requirements should apply to more states rather than none. See id. at 5-7; see also Franita Tolson, The Law of Democracy at a Crossroads: Reflecting on Fifty Years of Voting Rights and Judicial Regulation of the Political Thicket, 43 Fla. StATE U. L. Rev. 345, 350 (2016) (noting that "most states have used their power over voter qualifications, which is significantly broader in the wake of Shelby County, to sharply define and limit who can participate in elections. In the last few years alone, states have enacted dozens of laws that make it considerably harder to vote .... ."). Notably, the Shelby County decision also shifted the burden of proving the discriminatory impacts of voting laws from the covered governments (who had to show nondiscrimination) to disenfranchised voters, and it effectively shielded municipal ordinances related to voting from much scrutiny at all. Sam Levine \& Ankita Rao, In 2013 the supreme court gutted voting rights-how has it changed the US?, THE GUARDIAN (June 25, 2020, 13:14 EDT), https://www.theguardian.com/usnews/2020/jun/25/shelby-county-anniversary-voting-rights-act-consequences.

${ }^{32}$ Congressional Research Service, Child Labor in America: History, Policy, and Legislative Issues 1 (as updated 2013), available at https://www.everycrsreport.com/files/20131118 RL31501 008741c7351fd72ae2a262198ba9c0e4 4921a60a.pdf. See also Joanna Grisinger, Book Review, James D. Schmidt, Industrial Violence and the Legal Origins of Child Labor, 28 L. \& HIST. REV. 649, 649-50 (2011) (“describing nineteenthcentury producerist ideology, which valued individuals as workers. For Appalachian working families, clear lines between childhood and adulthood were absent. Instead, children were brought into the workplace to perform tasks appropriate to their size and skill level, growing into their roles as workers as they became adults."). 
$1906,{ }^{33}$ culminating in the passage of the Fair Labor Standards Act in $1938 .{ }^{34}$ As is true for many new regulatory regimes affecting business, employers initially resisted the restrictions on child labor, necessitating additional restrictions and improved enforcement. ${ }^{35}$ However, "since roughly the late 1980s, child labor in its various aspects has largely disappeared from the policy scene; the issue is often viewed as a remnant of an earlier period in American history." 36

Nevertheless, despite the apparent normification of child labor prohibitions and restrictions, no group strongly advocates that these restrictions have become unnecessary. In the terms of this Article, successive generations of U.S. society have not forgotten that child labor restrictions continue to provide important protections to children. That memory remains accessible in part because evidence indicates that many employers still violate restrictions on child labor, especially with respect to adolescents and immigrant children. ${ }^{37}$ Moreover, advocates for children often view these public law protections of children as incomplete, ${ }^{38}$ with organizations like the American Federation of Teachers seeking to extend existing

${ }^{33}$ However, its early efforts were often unsuccessful. See, e.g., Constitutional Law-Federal Child Labor Law Invalid, 27 YALE L.J. 1092, 1092-93 (1918) (summarizing the then-recent Supreme Court decision).

${ }^{34}$ Congressional Research Service, supra note 32 at 2-5. The Fair Labor Standards Act is codified as 29 U.S.C. $\S \S 201-219$, and the child labor prohibitions are found in Section 212.

${ }^{35}$ Congressional Research Service, supra note 32, at 5 (citation omitted).

${ }^{36} \mathrm{Id}$. at 1 .

${ }^{37}$ Priyanka Boghani, Q\&A:America's “Invisible” Child Labor Problem, PBS FronTLINE (April 24, 2018), https:/www.pbs.org/wgbh/frontline/article/qa-americas-invisible-child-labor-problem/; Alana Semuels, How Common Is Child Labor in the U.S.?, ThE ATLANTIC (Dec. 15, 2014), https:/www.theatlantic.com/business/archive/2014/12/how-common-is-chid-labor-in-the-

us/383687/; Kimberly J. Rauscher, Carol W. Runyan, Michael D. Schulman, \& J. Michael Bowling, US Child Labor Violations in the Retail and Service Industries: Findings From a National Survey of Working Adolescents, 98:9 AMER. J. PUB. HEALTH 1693, 1693-98 (2008), doi: 10.2105/AJPH.2007.122853; Ana Maria Echiburu, Immigration Raid Results in Charges Filed Against Iowa Slaughterhouse for Child Labor Violations, 14 PUBLIC INTEREST L. REP. 93, 94 (2008) ("Child labor laws in Iowa prohibit children below the age of eighteen from working in a meatpacking plant. Employees in meat packing plants are exposed to dangerous machines and chemicals and often have to make thousands of cuts every day with sharp knives, risking lacerations, nerve damage, or muscle damage. The brutal environment of a meatpacking plant is not an appropriate place for children. Yet, the May 12 immigration raid of Agriprocessors in Iowa, uncovered underage employees working in such conditions, which is something Americans are unaccustomed to hearing about in the United States."); Susan Makdisi, Student Essay, Child Labor, 4 LOY. PoverTy L.J. 281, 281 (1998) ("Imagine a place where children go to work on farms, in factories, on the streets, or in an industry, working five to sixteen hours a day, five to seven days a week. ... This happens all over the world, including America and other developed countries.").

${ }^{38}$ E.g., Meret Thali, Note, Missing Childhood: How Cultural Norms and Government Systems Continue to Support Child Labor in Agriculture, 20 DrAKE J. AgriCulturAL L. 453, 454-55 (2015) ("This widespread general acceptance and promotion of children working in agriculture in the United States has led to federal legislation that has failed to protect these children, even though they are working in what is considered one of the three most dangerous sectors of labor."). 
restrictions to agriculture, which the Fair Labor Standards Act largely exempts. ${ }^{39}$ Problem not, in other words, completely solved.

As with the Voting Rights Act, however, the success of a public law regime can be so (apparently) complete that people come to believe that its restrictions are no longer necessary. Under the influence of the regulatory shifting baseline syndrome, the (apparent) disappearance of the problem transforms an initial cultural respect for the regulatory regime (it worked!) into a psychological resetting of the regulatory baseline - essentially, "we no longer have to worry about that problem and these laws are now an impediment to other things we want to do." In particular, the disappearance of a specific problem can allow interest groups to re-frame the corrective regulatory regime as unnecessary, burdensome, expensive, or an infringement of private or states' rights. In short, the perceived regulatory baseline shifts, inducing policymakers and legislators to view the existing legal regime as no longer necessary and perhaps even harmful, opening those legal protections to political re-evaluation, undermining, and perhaps even elimination. At the extreme, the political and policymaking systems wipe their cultural memory, countervailing pressures induce politicians and legislatures to dismantle or weaken the nowdevalued regimes - and history repeats itself.

Applying a regulatory shifting baseline syndrome analysis to evolving and often contentious public debates therefore has the potential to reveal an important cultural component to the evolution of public law and policy: people, including politicians and legislators, forget the past, and this generational amnesia can change the contours of the relevant political and legal debate. This generational amnesia allows both government officials and the affected members of the public to question past regulatory decisions and past risk assessments in ways that would have been laughable two or three generations ago.

This Article argues that identifying and resisting the regulatory shifting baseline syndrome offers one means of keeping needed public protections in place, avoiding the re-emergence of public commons problems that momentarily appear to have been "solved." Specifically, awareness of the regulatory shifting baseline syndrome should prompt a reframing of the status of the public problem under consideration from the objective manifestation (in Shelby County, racial disparities in voter registration) to the human impulses underlying that manifestation (in Shelby County, the impulse to discriminate). In so doing, the relevant questions for evaluating the regime's continued existential value become not just Did it work? (racial disparities eliminated, at least momentarily) but also - and for purposes of avoiding the regulatory shifting baseline syndrome, more importantly-What is likely to happen when the regime's protections are removed?

This Article proceeds in four parts. Part I introduces the shifting baseline syndrome in its original context, then transitions the psychology of fisheries regulation into the regulatory shifting baseline syndrome. Part II examines the 2008

39 Child Labor in the United States, Amer. Fed. Teachers (as viewed January 23, 2021), https://www.aft.org/community/child-labor-united-states. 
financial crisis as an example of this syndrome operating across multiple financial developments that nevertheless illustrate regulators' repeated susceptibility to discounting the vulnerability of our economic system to systemic risk resulting from individual profit-seeking. In Parts III and IV, this Article re-frames two current public debates - the resistance to childhood vaccination and the convoluted debate over the breadth of "waters of the United States" under the federal Clean Water Act - as evidence of the regulatory shifting baseline syndrome in operation. Specifically, this Article argues that both controversies are inextricably bound up in cultural "forgettings" that are, paradoxically, the perverse result of the previous and highly successful laws and policies governing these two issues. Recapturing the cultural memories that those two regulatory regimes embody should thus be an important first step in both: (1) understanding the revaluations of those regimes currently in process; and (2) reminding the affected communities of why those regimes came to exist in the first place and their continuing roles in preventing the evils whose absence the general public and legislators now take for granted.

Like the fisheries scientists who discovered the shifting baseline syndrome, this Article concludes that the re-animation of historical knowledge and cultural memory is an important corrective to the regulatory shifting baseline syndrome. However, the emphasis here is different. In the ecological shifting baseline syndrome, historical reconstruction informs the creation of new regulatory goals. In the regulatory shifting baseline syndrome, in contrast, accurate historical reconstruction and revival of cultural memory, with full appreciation of regulatory regimes as memory institutions, serves to prevent policymakers, legislatures, and courts from whittling away at seemingly outdated rules by reminding them that the rules are the reason that the societal evil has gone away-i.e., the regulatory regime worked, and, more importantly, is still working, to curb individual human behaviors that damage the greater public good.

\section{The Shifting Baseline Syndrome in Fisheries AND OTHER ECOLOGICAL MANAGEMENT}

Humans forget things, both individually and in societal groups. Such forgettings can have significant consequences regarding when, how, and to what extent societies regulate to protect the general public good. In natural resource management, for example, one of the most well-studied and consequential phenomena resulting from this cultural amnesia has been the shifting baseline syndrome. First identified in marine fisheries management, the shifting baseline syndrome results from a society's collective inability to accurately remember historical ecological conditions and compare them to existing conditions, skewing the focus and goals of natural resource management from what might be considered optimal.

This Part explores the origins of the shifting baseline syndrome in natural resource management in order to highlight the solutions identified to counteract the 
syndrome. Specifically, biologists and ecologists of all specialties have increasingly embraced the need to reconstruct historical states in order to recapture forgotten understandings of what is "normal." These recaptured cultural memories can then inform contemporary regulation by, at the very least, identifying a wider range of potential management goals.

\section{A. Daniel Pauly's Insight: The Origin of the Shifting Baseline Syndrome}

In 1995, marine biologist Daniel Pauly coined the term "shifting baseline syndrome" to identify a key problem in fisheries management and modeling: fisheries scientists were becoming separated "from the biologists studying marine or freshwater organisms and/or communities," leading those scientists "to factor out ecological and evolutionary considerations from our models." ${ }^{\prime 40}$ The resulting myopic focus on fishers, fishing fleets, and catch numbers induced the syndrome, which

has arisen because each generation of fisheries scientists accepts as a baseline the stock size and species composition that occurred at the beginning of their careers, and uses this to evaluate changes. When the next generation starts its career, the stocks have further declined, but it is the stocks at that time that serve as a new baseline. The result obviously is a gradual shift of the baseline, a gradual accommodation of the creeping disappearance of resource species, and inappropriate reference points for evaluating economic losses resulting from overfishing, or for identifying targets for rehabilitation measures. ${ }^{41}$

What fisheries scientists needed, Pauly continued, was a method for incorporating historical observations of fisheries abundance and species diversity - generally dismissed as "anecdotes"-into contemporary fishery management policy, much as contemporary astronomers incorporate ancient observations "of sunspots, comets, supernovae, and other phenomena" and oceanographers continue to make use of the physical data collected by mariners from at least the 19th century. ${ }^{42}$ Citing two such historical looks at fishing impacts with approval, Pauly concluded that "[f]rameworks that maximize the use of fisheries history would help us to understand and to overcome - in part at leastthe shifting baseline syndrome, and hence to evaluate the true social and ecological costs of fisheries." 43

${ }^{40}$ Pauly, supra note 5 , at 430 .

${ }^{41} I d$.

${ }^{42} I d$.

${ }^{43}$ Id. 


\section{B. Use of the Shifting Baseline Syndrome in Fisheries Management}

Pauly and other marine scientists have now documented the shifting baseline syndrome in fisheries around the world. ${ }^{44}$ Moreover, these scientists have institutionalized the collection of historical fisheries data as one means of counteracting the syndrome, ${ }^{45}$ essentially arguing that the more they can document the actual historical state of fisheries and marine ecosystems, the greater the chance that fisheries policies and catch limits will reflect both the true historical abundance of targeted fish species and the complexity of the marine ecosystems of which these species were a part.

Legal scholars, in turn, have argued that emerging historical insights into ecosystem change from these biological and ecological reconstructions should broadly inform current marine management policy and law. ${ }^{46}$ Moreover, historical

${ }^{44}$ E.g., Fiona T. Francis, Brett R. Howard, Adrienne E. Berchtold, Trevor A. Branch, Laís C.T. Chaves, Jillian C. Dunic, Brett Favaro, Kyla M. Jeffrey, Luis Malpica-Cruz, Natalie Maslowski, Jessica A. Schultz, Nicola S. Smith, \& Isabelle M. Côté, Shifting headlines? Size trends of newsworthy fishes, 7 PEERJ e6395 (2019), doi: 10.7717/peerj.6395; H.A. Maia, R.A. Morais, A.C. Siqueira, N. Hanazaki, S.R. Floeter, \& M.G. Bender, Shifting baselines among traditional fishers in São Tomé and Príncipe islands, Gulf of Guinea, 154 Ocean \& Coastal Management 133, 133-142 (2018), https://doi.org/10.1016/j.ocecoaman.2018.01.006; Sean Berger, Historical Ecology and Shifting Baseline Syndrome in the Kawartha Lakes, Ontario (M.A. Thesis, Trent University, 2018), available at https://search.proquest.com/docview/2042371835?pqorigsite=primo; Maite Erauskin-Extramiana, Sharon Z. Herzka, Gustavo Hinojosa-Arango, \& Octavio Aburto-Oropeza, An interdisciplinary approach to evaluate the status of large-bodied Serranid fisheries: The case of Magdalena-Almejas Bay lagoon complex, Baja California Sur, Mexico, 145 OCEAN \& COASTAL MANAGEMENT 21, 21-34 (2017), https://doi.org/10.1016/j.ocecoaman.2017.05.005; Annabel A. Plumeridge \& Callum M. Roberts, Conservation targets in marine protected area management suffer from shifting baseline syndrome: A case study on the Dogger Bank, 116 Marine Pollution Bull. 395, 395-404 (2017), https://doi.org/10.1016/j.marpolbul.2017.01.012; Tomaso Fortibuoni, Diego Borme, Gianluca Franceschini, Otello Giovanardi, \& Sasa Raicevich, Common, rare or extirpated? Shifting baselines for common angelshark, Squatina squatina (Elasmobranchii: Squatinidae), in the Northern Adriatic Sea (Mediterranean Sea), 772 Hydrobiologia 247, 247-51 (2016), DOI: http://dx.doi.org/10.1007/s10750-016-2671-4; A. J. Venkatachalam, A. R. G. Price, S. Chandrasekara, S. Senaratna Sellamuttu, \& J. Kaler, Changes in Frigate Tuna Populations on the South Coast of Sri Lanka: Evidence of the Shifting Baseline Syndrome from Analysis of Fisher Observations, 20 MARINE \& FRESHWATER ECOSYSTEMS 167, 167-76 (2010), https://doiorg.ezproxy.lib.utah.edu/10.1002/aqc.1068; Samuel T Turvey, Leigh A. Barrett, Hao Yujiang, Zhang Lei, Zhang Xivqiao, Wang Xianyan, Huang Yadong, zhou Kaiya, Tom Hart, \& Wang Ding, Rapidly Shifting Baselines in Yangtze Fishing Communities and Local Memory of Extinct Species, 24 Conservation Biology 778-87 (2010); Cameron H. Ainsworth, Tony J. Pitcher, \& Christovel Rotinsulu, Evidence of Fishery Depletion and Shifting Cognitive Baselines in Eastern Indonesia, 141 BIOlOGiCAL CONSERVATION 848-859 (2008), https://doi.org/10.1016/j.biocon.2008.01.006.

${ }^{45}$ E.g., Dirk Zeller, Rainer Froese, \& Daniel Pauly, On Losing and Recovering Fisheries and Marine Science Data, 29 MARINE POL'Y 69, 69-73 (2005), https://doi.org/10.1016/j.marpol.2004.02.003; Jeremy B.C. Jackson et al., Historical Overfishing and the Recent Collapse of Coastal Ecosystems, 293 SCIENCE 629-637 (2001).

${ }^{46}$ E.g., Eric A. Bilsky, Conserving Marine Wildlife through World Trade Law, 30 Michigan Journal of InTERnational Law 599, $602-03$ (2009); Robin Kundis Craig, Taking Steps Toward 
reflection on the law's influence on a particular fishing industry over time can suggest improvements to the regulation of that industry. ${ }^{47}$ Even Pauly himself published in a law review to argue that the historical evidence of dramatic reductions in marine fish stocks necessitates the legal creation of marine reserves as well as the elimination of subsidies to fishers. ${ }^{48}$

\section{The Shifting Baseline Syndrome in Ecology, Conservation, and Ecological Management}

As a concept, the shifting baseline syndrome has also moved beyond fisheries. In particular, researchers have acknowledged the importance of this syndrome to other areas of ecological regulation, such as endangered species protection, ${ }^{49}$ ecological restoration, ${ }^{50}$ and ecosystem management more generally. ${ }^{51}$ Under this more generalized conception of "environmental generational amnesia," 52 "each generation grows up being accustomed to the way their environment looks and feels, and so, in a system experiencing progressive impoverishment, they do not recognize how degraded it has become over the course of previous generations." 53 Multiple studies outside of fisheries have empirically demonstrated intergenerational differences in resource perception, from bird species in Yorkshire to deforestation in the Beni, Bolivia, to water availability and quality in Alaska. ${ }^{54}$ These studies indicate that the shifting baseline syndrome operates in regulatory regimes to keep ecosystems in impoverished states, ${ }^{55}$ but they also suggest that when historical reconstructions can take hold and correct those shifted perceptions,

Marine Wilderness Protection? Fishing and Coral Reef Marine Reserves in Florida and Hawaii, 34 McGeorge Law REVIEw 155, 157 (2003); Robin Kundis Craig, Taking the Long View of Ocean Ecosystems: Historical Science, Marine Restoration, and the Oceans Act of 2000, 29 ECOLOGY LAW QUARTERLY 649 (2002).

${ }^{47}$ Danielle Ringer, Courtney Carothers, Rachel Donkersloot, Jesse Coleman, \& Paula Cullenberg, For generations to come? The privatization paradigm and shifting social baselines in Kodiak, Alaska's commercial fisheries, 98 MARINE POL'Y 97, 97-103 (2018), https://doi.org/10.1016/j.marpol.2018.09.009.

48 Daniel Pauly, Unsustainable Marine Fisheries, 7 Sustainable DeVelopment L. \& Pol'y 10, 10-11 (2006).

49 E.g., Frank Sturges, Humane Society of the United States v. Zinke (D.C. Cir 2017): Shifting Baselines in the Endangered Species Act, 43 HARVARD ENVTL. L. REV. 225 (2019).

${ }^{50}$ Matias Guerrero-Gatica, Enrique Aliste, \& Javier Simonetti, Shifting Gears for the Use of the Shifting Baseline Syndrome in Ecological Restoration, 11 SUSTAINABILITY 1458 (2019).

${ }^{51}$ Masashi Soga \& Kevin J. Gaston, Shifting Baseline Syndrome: Causes, Consequences, and Implications, 16 FRONTIERS IN ECOLOGY AND THE ENVIRONMENT 222-30 (2018).

52 P.H. Kahn Jr., Children's affiliations with nature: structure, development, and the problem of environmental generational amnesia, in CHILDREN AND NATURE: PSYCHOLOGICAL, Sociocultural, And Evolutionary InVEstigations (P.H KAHN JR. \& S.R. Kellert EDS.) 93, 93-94 (Cambridge, MA: MIT Press, 2002).

53 Soga \& Gaston, supra note 51, at 222.

${ }^{54} I d$. at 223 .

${ }^{55}$ Guerrero-Gatica, Aliste, \& Simonetti, supra note 50, at 1460; Soga \& Gaston, supra note 51, at 222. 
more productive management decisions and even, in some cases, restoration become possible. Arguably, therefore. "the fundamental driver of [the shifting baseline syndrome is the lack, or paucity, of relevant historical data on the natural environment." "W6 "Without reliable historical environmental data, people cannot infer whether long-term environmental changes have occurred, nor to what extent, and so they have little choice but to define baselines according to their own knowledge and experiences ...."57

Ecological studies of the shifting baseline syndrome outside of fisheries have been increasing, with direct expectations for policymakers and managers. ${ }^{58}$ For example, defining the shifting baseline syndrome "as a downward shift in perceptions or expectations of an environmental baseline as a consequence of biological change," Guerrero-Gatica et al. argue that accurate descriptions of how the shifting baseline syndrome is actually operating in a given specific system may not only improve conservation and restoration efforts but also identify mismatches in science-based management goals and community expectations. ${ }^{59}$ In turn, Soga and Gaston traced three specific consequences of the shifting baseline syndrome, all of which are directly relevant to environmental policymaking. "The first, and most immediate, is an increased societal tolerance for progressive environmental degradation, including declining wildlife populations, loss of natural habitats, and increasing pollution." "S0 "Second, [the shifting baseline syndrome] is also likely to alter people's expectations as to what is a desirable (i.e. worth protecting) state of the natural environment." 61 "Third, if policy makers and resource managers have false perceptions of past environmental conditions, they may set inappropriate targets for environmental conservation, restoration, and management programs." ${ }^{\prime \prime 2}$ Thus, they advocate increasing monitoring and data collection, including reconstructing historical conditions from the available data. ${ }^{63}$

Notably, recovering historical ecological data can correct current management misperceptions in multiple directions. While, for the most part, such historical reconstructions confirm that contemporary perceptions of "normal" are in fact highly impoverished, occasionally other lessons emerge. For example, an historical reconstruction of Caribbean monk seal populations indicates that the species' population was always small and fragmented and that its extinction resulted from a number of factors, challenging the common wisdom that human hunters decimated a large and thriving population. ${ }^{64}$ Thus, sometimes contemporary assumptions

56 Soga \& Gaston, supra note 51, at 224.

${ }^{57}$ Id.

${ }^{58}$ Guerrero-Gatica, Aliste, \& Simonetti, supra note 50, at 1462 \& 1463 fig. 2.

${ }^{59} \mathrm{Id}$. at 1467-68.

${ }^{60}$ Soga \& Gaston, supra note 51, at 225.

${ }^{61} \mathrm{Id}$.

${ }^{62} \mathrm{Id}$. at 226 (citations omitted).

${ }^{63}$ Id. at 226-28.

${ }^{64}$ Julio A. Baisre, Shifting Baselines and the Extinction of the Caribbean Monk Seal, 27 CONSERV. BIOL 927, 933 (2013), DOI: 10.1111/cobi.12107. 
about how we arrived at current realities are just wrong. ${ }^{65}$

\section{From Ecology to Regulatory Regimes: The Regulatory Shifting Baseline Syndrome}

Because the shifting baseline syndrome has always emerged from subjective human perception and psychology rather than objective ecological reality, there is no reason that human "forgetting" (societal or generational amnesia) would not be an important factor in other areas of human management besides fisheries and ecological conservation. Indeed, commenters have concluded that the syndrome has been at work in everything from personal weight gain ${ }^{66}$ to government and business leadership ${ }^{67}$ to religious doctrine ${ }^{68}$ to the acceptance of non-tenure track positions in higher education. ${ }^{69}$

To deal with these multiplying applications of "shifting baseline syndrome," conservation biologists helpfully have identified two forms of the syndrome: generational amnesia and personal amnesia. ${ }^{70}$ Like Pauly's original characterization of the shifting baseline syndrome in fisheries, this Article is more interested in generational amnesia, which "describes individuals setting their perceptions from their own experience, and failing to pass their experience on to future generations. Thus, as observers leave a system, the population's perception of normality up-dates and past conditions are forgotten."71 This form of the shifting baseline syndrome "is a cautionary tale referring to changing human perceptions of biological systems due to loss of experience about past conditions." 72 Viewing the

\footnotetext{
${ }^{65}$ See also, e.g., Simon Albert, Mark Love, \& Tom D. Brewer, Contrasts in Social and Ecological Assessments of Coral Reef Health in Melanesia, 67 PAC. SCI. 409, 409-24 (2013) (concluding that residents of the Solomon Islands perceive their coral reefs to be more degraded from historical conditions that they actually are, while people in Fiji failed to perceive that their coral reefs had degraded).

${ }^{66}$ Randy Olson, Slow Motion Disaster Below the Waves, L.A. TIMES (Nov. 17, 2002 12:00 AM PT), https://www.latimes.com/archives/la-xpm-2002-nov-17-op-olson17-story.html ("If your ideal weight used to be 150 pounds and now it's 160 , your baseline - as well as your waistline - has shifted.").

${ }^{67}$ Art Petty, Leadership and Shifting Baseline Syndrome, Gov'T EXEC. (April 28, 2017), https://www.govexec.com/management/2017/04/leadership-and-shifting-baselinesyndrome/137276/.

68 Matt, Shifting Baseline Syndrome and the Church, ChurchThought (Oct. 21, 2013), http://churchthought.com/shifting-baseline-syndrome-church/.

${ }^{69}$ Josh Boldt, Off Track: Higher Education's Shifting Baseline Syndrome, CHRONICLE OF HigHER EDUCATION (Dec. 10, 2013), https://community.chronicle.com/news/211-off-track-highereducation-s-shifting-baseline-syndrome.

${ }^{70}$ S.K. Papworth, J. Rist, L. Coad, \& E.J. Milner-Gulland, Evidence for shifting baseline syndrome in conservation, 2 CONSERVATION LETTERS 93, 93 (2009), doi: 10.1111/j.1755-263X.2009.00049.x.

${ }^{71} I d$. (citations omitted). In contrast, "Personal amnesia describes individuals updating their own perception of normality; so that even those who experienced different previous conditions believe that current conditions are the same as past conditions." Id.

${ }^{72} I d$.
} 
syndrome more broadly, it is from this generational perspective on societal amnesia that the role of public law as a memory institution becomes most important, allowing regulatory regimes to remind future generations why they exist.

One should always be cautious in hoping that more information will change people's minds about public policy. ${ }^{73}$ Even in ecological studies, scientists recognize that "the availability of (even very good) empirical evidence has not always been sufficient to convince people of historical trends in environmental conditions. Recent examples of belief- rather than evidence-based environmental policy making raise the possibility that [the shifting baseline syndrome] could even accelerate in an age of increasing data availability." 74

Nevertheless, efforts to identify and correct the regulatory shifting baseline syndrome may have an advantage over efforts to correct ecological shifting baseline syndromes. While ecological change might have many causes,${ }^{75}$ and historical accounts of prior bounty dismissed as exaggerated tall tales, ${ }^{76}$ there is no escaping the fact that humans, and humans alone, create regulatory regimes. Therefore, the fact that past legislatures, regulatory agencies, and other policymakers bothered to engage in this labor is inescapable evidence that they thought something was wrong. In this very real sense, public law is historical knowledge, and its persistence over time renders it a cultural memory institution.

There are, of course, excellent reasons to change established regulatory regimes. As the Introduction noted, legal regimes grounded in an outdated scientific model of how ecological and biogeological systems actually function should be updated to reflect new science. Evolving conceptions of ethics and morality may also undermine past legal regimes; in the United States, the abolishment of slavery ${ }^{77}$ and the progressive elimination of the death penalty ${ }^{78}$ are two prominent examples of this motivation for legal change.

Nevertheless, many public law regulatory regimes reflect the fact that we have

${ }^{73}$ E.g., Elizabeth Kolbert, Why Facts Don't Change Our Minds, THe New Yorker (Feb. 20, 2017), https://www.newyorker.com/magazine/2017/02/27/why-facts-dont-change-our-minds; Timothy D. Hanks \& Christopher Summerfield, Perceptual decision making in rodents, monkeys, and humans, 93 NEURON 15, 22 (2017).

${ }^{74}$ Soga \& Gaston, supra note 51, at 224.

${ }^{75}$ Katharina E. Fabricius \& Glenn De'ath, Identifying Ecological Change and Its Causes: A Case Study on Coral Reefs, 14 Ecol. Applications 1448, 1448 (2004), https://doi.org/10.1890/03-5320.

${ }^{76}$ Loren McClenachan, Andrew B. Cooper, Matthew G. McKenzie, \& Joshua A. Drew, The Importance of Surprising Results and Best Practices in Historical Ecology, 65 BIOSCIENCE 932, 932-33, 938 (2015), https://doi.org/10.1093/biosci/biv100.

${ }^{77}$ U.S. CONST., amend 13, § 1 (ratified 1865).

${ }^{78}$ E.g., Kennedy v. Louisiana, 554 U.S. 407, 413 (2008) (holding that the Eighth Amendment bars Louisiana from imposing the death penalty as a sanction for the rape of a child when the crime did not result, and was not intended to result, in the death of the child); Atkins v. Virginia, 536 U.S. 304, 321 (2002) (holding unconstitutional Virginia's application of the death penalty to the mentally disabled); Thompson v. Oklahoma, 487 U.S. 815, 838 (1988) (holding that imposition of the death penalty is unconstitutional when the defendant committed the murder at age 15); Woodson v. North Carolina, 428 U.S. 280, 286-305 (1976) (holding that North Carolina's mandatory death penalty for first-degree murder is unconstitutional). 
learned something important about ourselves as human beings - particularly about the cumulative societal impacts of multitudinous (e.g., polluters) or domineering (e.g., 19th-century monopolists) individual behavioral impulses playing out on a national stage, destabilizing or otherwise deleteriously affecting various aspects of the public commons. ${ }^{79}$ As the next three parts suggest, these experiential lessons, memorialized in regulatory regimes, are unlikely to lose their value unless and until human nature itself fundamentally transforms. They explore the workings of the regulatory shifting baseline syndrome in three very different contexts-financial regulation, vaccines, and water quality protection - to suggest the different ways in which the syndrome can illuminate and inform discussions of whether and how to reform public law regimes.

\section{Reconceptualizing the 2008 Economic Crash as the Product of A REgUlatory SHIFTING BASELINE SYNDROME}

There are many, many ways to tell the story of the 2008 financial crisis. "Unrelenting greed," for example, is a popular narrative, particularly in Hollywood movies. ${ }^{80}$ "Regulators asleep at the wheel" is another. ${ }^{81}$ More academically, the crash can be considered one of several critical junctures in corporations and

\footnotetext{
${ }^{79}$ While the fit is not always exact, this article refers to many of the public goods (however aspirational some of them remain) of U.S. society - equal access to voting and other aspects of political processes, a stable economy, public health, a clean environment - as commons resources or common-pool resources in the sense that Elinor Ostrom and her co-authors defined it: "natural and human-constructed resources in which (i) exclusion of beneficiaries through physical and institutional means is especially costly, and (ii) exploitation by one user reduces resource availability for others." Elinor Ostrom, Joanna Burger, Christopher B. Field, Richard B. Norgaard, \& David Policansky, Revisiting the Commons: Local Lessons, Global Challenges, 284 SCIENCE 278, 278 (1999). Public law often operations as an exclusion by limiting how individual entities (persons, corporations, political parties, even in some circumstances governments) can affect or operate with the relevant commons and often is quite costly (economically and politically) to enact/promulgate, build capacity for implementing, and enforce. Nevertheless, in the absence of those regimes, exploitation for the benefit of those individual entities can put the entire public good at risk for everyone. "Commons" terminology the aptly undergirds a discussion of the regulatory shifting baseline syndrome because both describe situations in which governance is an important option mediating the oft-occurring tensions between the drives and motivations of individual entities and the best interests of the public as a whole. As Garrett Hardin famously recognized in 1968, the unrestrained drives of individuals can lead to tragedies for the larger society. Garrett Hardin, The Tragedy of the Commons, 162 SCIENCE 1243, 1243-45 (1968). However, "tragedies of the commons are real, but not inevitable"-although the governance challenges multiply as the scale of the commons increases. Ostrom et al., supra, at 281-82.

${ }^{80}$ See, e.g., "The Big Short" (2015); "99 Homes" (2014); "The Queen of Versailles" (2012); "Margin Call" (2011); "Inside Job" (2010).

${ }^{81}$ See, e.g., Chana Joffe-Walt, Regulating AIG: Who Fell Asleep on the Job?, NPR ALL THINGS $\begin{array}{llllll}\text { CONSIDERED } & \text { (June } & 5, & \text { AM } & \text { ET), }\end{array}$ https://www.npr.org/templates/story/story.php?storyId=104979546; Tami Luhby, Bank regulators:"Asleep at the switch," CNN MONEY (March 4 2008: 5:33 PM EST), https://money.cnn.com/2008/03/04/news/companies/senatebank/index.htm.
} 
financial law, ${ }^{82}$ during which, "overall, there was a systemic breakdown in accountability and ethics that led to a crisis." 83

This Part contributes to this ongoing discussion by arguing that the 2008 financial crisis was also, at least in part, the product of a recurring regulatory shifting baseline syndrome in the United States. If, as Jeff Cohodes has recently argued, financial "regulation exists to both prevent the next financial crisis and systemic failures, as well as protect against an idiosyncratic bank failure in the future," but always operates in tension with banks' and financial firms' willingness to take risks to increase returns,${ }^{84}$ then the syndrome, induced by a perceived shifted baseline of market stability, helped to lead both firms and regulators to increase private-side risk at the expense of the economic commons' continued stability. In essence, the relevant players all forgot that unregulated banking and securities industries (and, yes, aided by the greed of some of their human constituents) are more than capable of introducing significant systemic risk into the national and global economic systems ${ }^{85}$ - a core historic lesson that the United States had already had to learn at least twice before.

Lesson \#1 occurred on October 29, 1929, "Black Tuesday," when the U.S. stock market crashed in a flurry of trading-16 million shares on the New York Stock

${ }^{82}$ Steven A. Bank \& Brian R. Cheffins, Corporate Law's Critical Junctures, Work in Progress presented at the USC Center for Law and Social Science Workshop, January 11, 2021.

${ }_{83}$ Jeff Cohodes, Perspectives on Dodd-Frank Act, Risk Management, and the Financial Crisis of 2008 from a Former Chief Risk Officer, 50 Loy. U. CHI. L.J. 533, 536 (2019).

${ }^{84} \mathrm{Id}$. at 533-34.

${ }^{85}$ In the words of Saule T. Omarova:

As this crisis demonstrated, the interconnection between retail financial markets and wholesale financial markets is a complex phenomenon, which raises serious questions about the continuing wisdom of a deregulatory approach to wholesale financial markets. Not only did the crisis show that even the wealthiest and the most financially savvy investors are vulnerable to irrational exuberance and, at times, outright fraud, it has also highlighted the extent of indirect exposure of the general investing public, the retail consumers of financial services, to the risks inherent in complex financial transactions in institutional markets.

Saule T. Omarova, The New Crisis for the New Century: Some Observations on the "Big Picture" Lessons of the Global Financial Crisis of 2008, 13 N.C. BANKING INST. 157, 161 (2009). Moreover:

More generally, the current financial crisis has brought to light that, as a result of rapid financial innovation in recent years, risk has become a financial asset in its own right. As a financial asset, risk is continuously dissected, priced, and traded in a variety of increasingly esoteric transactions among sophisticated entities. The financial crisis also drew attention to a hidden paradox: while this virtually limitless "slicing and dicing" of financial risk may decrease risk exposure for individual market players, it tends to increase the overall riskiness and vulnerability of the financial system.

Id. at 162 . 
Exchange in a single day. "Billions of dollars were lost, wiping out thousands of investors. In the aftermath of Black Tuesday, America and the rest of the industrialized world spiraled downward into the Great Depression (1929-39), the deepest and longest-lasting economic downturn in the history of the Western industrialized world up to that time." 87 The crash enacted a rather violent correction to the wide and often financially unfounded speculation that had occurred during the 1920s, "leaving stocks in great excess of their real value" in the face of declining production, rising unemployment, "low wages, the proliferation of debt, a struggling agricultural sector and an excess of large bank loans that could not be liquidated." 88

"The experience of the Great Depression changed attitudes regarding the regulation of financial markets." ${ }^{~} 99$ First, the 1929 crash spurred the development of U.S. securities law. ${ }^{90}$ "After a series of hearings that brought to light the severity of the abuses leading to the crash of 1929, Congress enacted the Securities Act of 1933 (the 'Securities Act'), and the Securities Exchange Act of 1934 (the 'Exchange Act')." ${ }^{\prime 1}$ Designed in particular to curb the lack of information, and often outright fraud, that had spurred the unwarranted investment frenzies of the 1920s, these laws required companies to disclose information about themselves and their securities and created significant liability for fraud. ${ }^{92}$

Second, the crash and the ensuing Depression led to changes in banking laws. ${ }^{93}$ Indeed, "Much of the current system is the result of changes put in place during the 1930s." 94 All told, "[t]he reforms in the first half of the twentieth century created a system of regulatory agencies, most of which remain today, that were organized by financial activity. Separate agencies focused on separate activities, often with very

86 Stock Market Crash of 1929, History.com (as updated April 6, 2020), https://www.history.com/topics/great-depression/1929-stock-market-crash.

${ }^{87} \mathrm{Id}$.

${ }^{88} \mathrm{Id}$.

${ }^{89}$ Matthew Sherman, Center for Economic and Policy Research, A Short History of Financial Deregulation in the United States 3 (July 2009), available at https://www.cepr.net/documents/publications/dereg-timeline-2009-07.pdf. The Glass-Steagall Act, also known as the Banking Act of 1933, was the Act of June 16, 1933, 48 Stat. 162, and is codified as amended at 12 U.S.C. $\S \S 641,71 \mathrm{a}, 197 \mathrm{a}, 221 \mathrm{a}, 227,263,333-339,348 \mathrm{a}, 371 \mathrm{a}-371 \mathrm{~d}, 374 \mathrm{a}, 375 \mathrm{a}$, 378,632 .

90 Legal Information Institute, Cornell Law School, Securities law history, https://www.law.cornell.edu/wex/securities law history (as viewed Sept. 7, 2020). See also Sherman, supra note 89, at 4 (describing these same developments).

${ }^{91}$ Id. The Securities Act of 1933, also known as the Fletcher-Rayburn Securities Act of 1933 or the Truth in Securities Act, was the Act of May 27, 1933, 48 Stat. 74, and is codified as amended as 15 U.S.C. $\S \S 77 \mathrm{a}-77$ aa. The Securities Exchange Act of 1934 was the Act of June 6, 1934, 48 Stat. 881, and is codified as amended at 15 U.S.C. $\S \S 78 \mathrm{a}-78 \mathrm{qq}$.

92 Legal Information Institute, Cornell Law School, Securities law history, https://www.law.cornell.edu/wex/securities_law history (as viewed Sept. 7, 2020).

${ }^{93}$ Sherman, supra note 89 , at 3-4.

${ }^{94}$ Id. at 3. See also Bank \& Cheffins, supra note 82, at 1-2 
different priorities." 95 These new regulatory regimes remained in place with only small changes for over four decades. ${ }^{96}$

After the United States climbed out of the Depression and emerged from World War II as an international superpower, it enjoyed over half a century of relative economic stability. To be sure, its economy was punctuated with bear markets and bull markets and the occasional recession, but it suffered nothing close to the systemic collapse that occurred on Black Tuesday. Problem apparently solved.

The problem seemed to be so well solved, in fact, that deregulation was deemed appropriate and desirable beginning in the 1980s. ${ }^{97}$ As other scholars have recognized, albeit it in different terms, the perceived baselines regarding the economy had shifted. For example, Israel Shaked, Paul D'Arezzo, and David Plastino have focused on changing attitudes about saving and having cash on hand. ${ }^{98}$ Importantly, however, they also note that:

These trends were likely aided by the so-called "great moderation" beginning in the early 1980 s that featured shorter and less severe economic downturns. Companies on both Wall Street and Main Street adapted to what were seen as new economic realities by deemphasizing the importance of internally generated cash flows and cash reserves. ${ }^{99}$

James R. Hackney, Jr., in turn, takes a more philosophical bent, locating the shifted baseline in the increasing "belief in market efficiency and informational role of prices," which, paradoxically, "held sway through such tumultuous economic times as the 1980s real estate boom and collapse that led to the savings and loan crisis, as well as the boom in the high-tech ("dot-com") industry in the 1990s."100 At the same time, comprehension of actual changes in market dynamics - real baselines that actually had moved-lagged, but it was these changes that allowed the crisis to become a global one. ${ }^{101}$

\footnotetext{
${ }^{95}$ Legal Information Institute, supra note 67, at 4.

${ }^{96} \mathrm{Id}$.

${ }^{97}$ Sherman, supra note 89, at 4-6; James R. Hackney, Jr., The Enlightenment and the Financial Crisis of 2008: An Intellectual History of Corporate Finance Theory, 54 ST. LouIs U. L.J. 1257, 1265 (2010). Notably, Alan Greenspan, one of the architects of financial deregulation during his 18-year chairmanship of the Federal Reserve Board, in 2008 "admitted that he had put too much faith in the self-correcting power of free markets and had failed to anticipate the self-destructive power of wanton mortgage lending." Edmund L. Andrews, Greenspan Concedes Error on Regulation, THE NEW YORK TIMES (Oct. 23, 2008), https://www.nytimes.com/2008/10/24/business/economy/24panel.html.

${ }_{98}$ Israel Shaked, Paul D'Arezzo, \& David Plastino, Financial Crisis of 2008 and Preliminary Framework for Analyzing Financially Distressed Firms, 27 AMER. BANKRUPTCY INST. J. 42, 42 (2009).

${ }^{99} I d$. (emphasis added).

${ }^{100}$ Hackney, supra note 97, at 1265.

${ }^{101}$ Omarova, supra note 85, at 157-60.
} 
In light of inflation rates in the late 1970s that made Depression-era caps on interest rates unworkable, "President Carter signed into law the Depository Institutions Deregulation and Monetary Control Act (DIDMCA) of 1980. The legislation established a committee to oversee the complete phase-out of interest rate ceilings within six years." ${ }^{102}$ More deregulation followed. ${ }^{103}$

The most immediate result of this deregulation was Lesson \#2: the savings and loan crisis of the 1980s. ${ }^{104}$ This crisis "was undoubtedly a failure of public policy. ... Institutions entered markets in which they had little experience, and a vulnerable industry expended beyond the reach of its federal safety net. Supervision and oversight activities proved to be insufficient, and early intervention was avoided in the name of regulatory forbearance." 105 Nevertheless, deregulation continued, aided by Alan Greenspan's appointment as Chairman of the Federal Reserve in August 1987. ${ }^{106}$ This deregulation included, for instance, the Gramm-Leach-Bliley Act of 1999, which repealed the post-Depression-era Glass-Steagall Act that had prohibited commercial banks from engaging in insurance and securities business. ${ }^{107}$ According to Hackney, "the belief in free markets had so permeated political thinking that Glass-Steagall seemed like an unnecessary regulatory artifact of the New Deal era."108 In 2000, Congress enacted the Commodity Futures Modernization Act (CFMA), "which limited federal regulation of most over-thecounter derivatives," 109 as a rider attached "to an 11,000-page spending bill."110

As one might predict, banks began combining functions, and financial firms of many sorts began experimenting with new forms of derivatives, including the mortgage-back derivatives that most directly precipitated the 2008 crisis. ${ }^{111}$ In 2011, the federal Financial Crisis Inquiry Commission singled out the CFMA and its undermining of securities regulation as a significant cause of new systemic risk in the U.S. economy that ultimately led to the 2008 financial crisis. ${ }^{12}$ More generally, however, the Commission concluded that "this financial crisis was avoidable": "The captains of finance and the public stewards of our financial

${ }^{102}$ Sherman, supra note 89, at 6. The Depository Institutions Deregulation and Monetary Control Act of 1980 was Public Law No. 96-211, 94 Stat. 132 (Mar. 31, 1980), codified as amended at 12 U.S.C. $\S \S 4 a, 93 a, 216-216 d, 1735 f-7 a, 1831 d$ and 15 U.S.C. $\S 1646$.

${ }^{103}$ Sherman, supra note 89 , at 6-8.

${ }^{104} \mathrm{Id}$. at 8 .

${ }^{105}$ Sherman, supra note 89 , at 8 .

${ }^{106} \mathrm{Id}$. at 8-11.

${ }^{107}$ Hackney, supra note 97, at 1265-66.

${ }^{108} I d$. at 1266.

109 Duncan Currie, Why Wall Street Collapsed, NAtional Review (Feb. 7, 2011), https://www.nationalreview.com/2011/02/why-wall-street-collapsed-duncan-currie/.

${ }^{110}$ Sherman, supra note 89, at 11.

${ }^{111} I d$. at 8-11.

112 Financial Crisis Inquiry Commission, The Financial Crisis Inquiry Report: Final REPORT OF THE NATIONAL COMMISSION ON THE CAUSES OF THE FINANCIAL AND ECONOMIC CRISIS IN THE UNITED STATES xxiv (Jan. 2011), available at https://cybercemetery.unt.edu/archive/fcic/20110310173545/http://c0182732.cdn1.cloudfiles.racks pacecloud.com/fcic_final_report_full.pdf. 
system ignored warnings and failed to question, understand, and manage evolving risks within a system essential to the well-being of the American public."113 In particular, and most relevant to this Article, "widespread failures in financial regulation and supervision proved devastating to the stability of the nation's financial markets." 114 Overconfidence and a shifted regulatory baseline were key components of the crisis:

The sentries were not at their posts, in no small part due to the widely accepted faith in the self-correcting nature of the markets and the ability of financial institutions to effectively police themselves. More than 30 years of deregulation and reliance on self-regulation by financial institutions, championed by former Federal Reserve chairman Alan Greenspan and others, supported by successive administrations and Congresses, and actively pushed by the powerful financial industry at every turn, had stripped away key safeguards, which could have helped avoid catastrophe. This approach had opened up gaps in oversight of critical areas with trillions of dollars at risk, such as the shadow banking system and over-the-counter derivatives markets. In addition, the government permitted financial firms to pick their preferred regulators in what became a race to the weakest supervisor. ${ }^{115}$

As in 1929, new regulation followed the 2008 crisis, notably the DoddFrank Act. ${ }^{116}$ Nevertheless, the fact that the pursuit of private profit in un- or underregulated banking and securities industries will eventually destabilize the entire economy seems to be a cultural memory that U.S. regulators find increasingly easy to forget: barely a decade after the 2008 crisis, the federal government began once again deregulate the financial industry. ${ }^{117}$

${ }^{113} I d$. at xvii.

${ }^{114} \mathrm{Id}$.

${ }^{115} I d$. at xviii.

${ }^{116}$ Dodd-Frank Wall Street Reform and Consumer Protection Act, Pub. L. No. 111-203, 124 Stat. 1376 (July 21, 2020), codified at 7 U.S.C. $\S \S 1 b, 6 b-1,6 r-6 s, 7 b-3,24 a, 26 ; 12$ U.S.C. §§ 4b, 16, 25b, 214d, 247b, 1465, 1467b, 1701x-2, 1831c, 1831o-1, 1850a, 1851-1852, 2806, 3353-3355, 4719, 5109, 5112, 5219a, 5219b, 5220b, 5301-5497, 5511-5567, 5581-5587, 5601-5628, 5641; 15 U.S.C. $\S \S 77 \mathrm{z}-2 \mathrm{a}, 78 \mathrm{c}-2$ to $78 \mathrm{c}-5,78 \mathrm{~d}-4$ to $78 \mathrm{~d}-9,78 \mathrm{j}-2$ to $78 \mathrm{j}-3,78 \mathrm{~m}-1,78 \mathrm{~m}-2,78 \mathrm{n}-1,78 \mathrm{n}-2,78 \mathrm{o}-$ 4a, 78o-7, 78o-9 to 78o-11 78u-6, 78u-7, 78pp, 80b-18b, 80b-18c, 1638a, 1639b-1639h, 1691c-2, 1693o-1, 1693o-2, 7220, 8201-8232, 8301-8325, 8341-8344; 18 U.S.C. § 3301; 22 U.S.C. § 286tt; and 31 U.S.C. $\S 313-314$.

${ }^{117}$ For example, Mark Lebovitch and Jacob Spaid warned in February 2019 that:

Nearly two years into the Trump presidency, extensive deregulation is raising risks for investors. Several of the administration's priorities are endangering financial markets by reducing corporate accountability and transparency. SEC enforcement actions under the Administration continue to lag previous years. The Trump administration has also instructed the SEC to study reducing companies' reporting 
It is true, of course, that particular market crashes are difficult to predict. It is also true that financial markets and instruments change, introducing both new benefits and new problems. What does not change, however, are the facts that individuals and firms want to make money and that their cumulative creativity in doing so can eventually introduce systemic risk into the economy as a whole. Recognizing this fact, Evan Turgeon has argued that the Depression-era regulatory baseline was the correct one- that is, "to best serve all members of society, the government should seek to mitigate market risk, while the market should seek to maximize rewards (which it already does).."118

Corporate and financial regulatory regimes thus offer fairly clear case studies of how periods of relative economic stability can induce a regulatory shifting baseline syndrome. The syndrome distorts perceptions of potential systemic risk, allowing private profit interests to push a deregulation agenda that undermines the public law regimes that protect the national (and now international) economic system. Arguably, U.S. governance is particularly susceptible to this specific manifestation of the syndrome because wide swaths of American society benefit from bull markets, undermining public resistance to regulatory "reform" that promises more of the same. New Deal-era statutes like the repealed Glass-Steagall Act thus still have an important cultural memory function to play in protecting the public economic commons, perhaps best summed up in a simple question: Would we be so eager to dismantle these rules if it were $1930 ?^{119}$

\section{RECONCEPTUALIZING THE CONTEMPORARY ANTI-VAXXER MOVEMENT AS A REgUlatory SHIFTING BASELINE SYNDROME}

The United States declared measles eliminated within its borders in 2000. ${ }^{120}$ Nevertheless, between mid-December 2014 and mid-February 2015, the Disney theme parks in Anaheim, California, appeared to be ground zero of a new measles outbreak. The Centers for Disease Control and Prevention (CDC) documented at

obligations to investors, including by abandoning a hallmark of corporate disclosure: the quarterly earnings report. Meanwhile, President Trump and Congress have passed new legislation loosening regulations on the same banks that played a central role in the Great Recession.

Mark Lebovitch \& Jacob Spaid, "In Corporations We Trust: Ongoing Deregulation and Government Protections," Harvard Law School Forum on Corporate Governance (Feb. 6, 2019), https:/corpgov.law.harvard.edu/2019/02/06/in-corporations-we-trust-ongoing-deregulation-andgovernment-protections/.

118 Evan N. Turgeon, Boom and Bust for Whom? The Economic Philosophy Behind the 2008 Financial Crisis, 4 VIRG. L. \& BUS. REV. 139, 182 (2009).

${ }_{119}$ My thanks to Acting Professor Menesh Patel, U.C. Davis School of Law, for this formulation.

120 Morgan Krakow, A tourist infected with measles visited Disneyland and other Southern California hot spots in mid-August, THE WASH. PosT (Aug. 24, 2019, 10:36 a.m. MDT), https://www.washingtonpost.com/health/2019/08/24/tourist-infected-with-measles-visiteddisneyland-other-southern-california-hotspots-mid-august/ 
least 125 measles cases in the United States that winter, 110 of which involved California residents. ${ }^{121}$ Of the California residents, 49 were unvaccinated, including 12 infants too young to be vaccinated; another 47 patients' vaccination status was unknown or undocumented; and a handful of others were undervaccinated (i.e., lacking the full course of shots). ${ }^{122}$ Notably, of the 37 vaccine-eligible patients who definitely were not vaccinated, 28 had purposely chosen to remain unvaccinated "because of personal beliefs." 123

Measles outbreaks in the United States spiked again in 2019, with the CDC confirming 1282 cases in 31 states. ${ }^{124}$ Noting that "[ $\left.\mathrm{t}\right]$ his is the greatest number of cases reported in the U.S. since 1992," it emphasized again that "[t]he majority of cases were among people who were not vaccinated against measles."125 Vaccination is a particularly important protection when it comes to measles because "[m] easles is one of the most contagious viruses in the world. Around 90 percent of unvaccinated people exposed to the virus will contract the disease within seven to 21 days," with death as one potential outcome. ${ }^{126}$

Measles has made a comeback in the United States and other countries because of "mistrust and misinformation campaigns about vaccine safety,"127 a phenomenon known more colloquially as the Anti-Vaxxer Movement. ${ }^{128}$ This Part argues that the contemporary Anti-Vaxxer Movement, and the relaxations of vaccine mandates that have both accompanied and promoted it, is potentially the most tragic example of the regulatory shifting baseline syndrome at work in the United States today.

\section{A. Vaccination and the Public Health Commons}

Although not as intuitively obvious as air or water, or even the national economy, public health is a commons resource, ${ }^{129}$ where the well-being of society

\footnotetext{
121 Jennifer Zipprich, Kathleen Winter, Jill Hacker, Dongxiang Xia, James Watt, \& Kathleen Harriman, Measles Outbreak - California, December 2014-February 2015, CENTERS FOR DISEASE Control \& Prevention Morbidity \& Mortality WeEkly Report (Feb. 20, 2015), https://www.cdc.gov/Mmwr/preview/mmwrhtml/mm6406a5.htm.

${ }^{122} \mathrm{Id}$.

${ }^{123} \mathrm{Id}$.

124 Centers for Disease Control \& Prevention, Measles Cases and Outbreaks (as updated Dec. 2, 2020), https://www.cdc.gov/measles/cases-outbreaks.html.

${ }^{125} \mathrm{Id}$.

${ }^{126}$ Krakow, supra note 120.

${ }^{127} \mathrm{Id}$.

${ }^{128}$ See, e.g., Katie M. Palmer, Why Did Vaccinated People Get Measles at Disneyland? Blame the Unvaccinated, WIRED (Jan. 8, 2015, 6:08 a.m.), https://www.wired.com/2015/01/vaccinatedpeople-get-measles-disneyland-blame-unvaccinated/ (noting that "most of the people stricken with Mickey Mouse measles do not understand how vaccines work, because they didn't get them. The vast majority of the infected were unvaccinated against the disease, including kids who were too young for the shots and anti-vaxxers who chose against them. That's how you get an outbreak.").

${ }^{129}$ Kevin M. Malone \& Alan R. Hinman, Vaccination Mandates: The Public Health Imperative and Individual Rights, in LAW In PUBlic HeAlth PRACTICE (Richard A. Goodman, Richard E. Hoffman,
} 
as a whole depends upon - and can be destroyed by - the cumulative effects of individual choices. For the first time in many decades, all Americans experienced this reality firsthand in the 2020-2021 pandemic, and that experience should have revived cultural memories regarding the importance of public health regimes that reduce the risks of dying from dread diseases. Whether a substantial majority of Americans will remember remains in some question, but the pandemic and the public's recurring rejection of masks and social distancing has brightly illuminated the public-private interplay of public health.

This dynamic between individual behavior and collective health is also at play with respect to vaccine-preventable diseases. Sufficiently large numbers of individual choices to get vaccinated against a particular disease eventually creates herd immunity. ${ }^{130}$ Herd immunity, in turn, protects those individuals who either cannot be vaccinated or who fall within the small percentage of vaccinated individuals who do not develop a strong enough immune response to keep them from getting the disease. ${ }^{131}$ Thus, reducing private and public disease risk from these diseases are inextricably intertwined.

Moreover, public health professionals already recognize that vaccination programs can shift both the objective societal disease regulatory baseline and the subjective individual risk-risk calculation of getting vaccinated. ${ }^{132}$ Vaccines thus present an interesting case study of the regulatory shifting baseline syndrome because successful vaccination programs create both legitimate and objectively verifiable shifts in the regulatory baseline and illegitimate and subjective regulatory shifting baseline syndromes. Legitimate shifts result from scientifically valid recalculations of public health risks as vaccines eradicate or radically attenuate a disease risk at a societal level. Most famously, smallpox killed about 30\% of the roughly 50 million people globally who contracted the disease each year before vaccination programs began in earnest in the 1950s. ${ }^{133}$ As a result of these vaccination efforts, however, the last natural case of smallpox occurred in 1977. ${ }^{134}$ The variola virus that causes smallpox now exists only in laboratories, and "[r] outine smallpox vaccination among the American public stopped in 1972 after the disease was eradicated in the United States." 135

\footnotetext{
Willfredo Lopz, Gene W. Matthes, Mark Rothstein, \& Karen Foster, eds.) 262, 263 (2007) (citing Garrett Hardin, The tragedy of the commons, 162 SCIENCE 1243, 1243-48 (1968)).

${ }^{130}$ Palmer, supra note 128; Malone \& Hinman, supra note129, at 264 (describing herd immunity and how the percentage of the vaccinated population required varies by disease).

131 Palmer, supra note 128; Malone \& Hinman, supra note129, at 264 (describing herd immunity and how the percentage of the vaccinated population required varies by disease).

132 Malone \& Hinman, supra note 129, at 263.

${ }^{133}$ World Health Organization, Bugs, Drugs, and Smoke: Stories from Public Health 35 (2011), available through https://www.who.int/about/history/publications/public_health_stories/en/.

${ }^{134} \mathrm{Id}$. at 3 .

135 Vaccine Basics, Centers for Disease Control \& Prevention (as updated July 12, 2017), https://www.cdc.gov/smallpox/vaccine-basics/index.html.
} 
A less dramatic example of a legitimate regulatory baseline shift occurred with polio. The polio vaccine exists in two primary forms. The oral polio vaccine is more effective at preventing polio but carries with it a risk of paralysis, which occurs at a rate of about 1 in every 2.4 million doses of the vaccine. ${ }^{136}$ The inactivated polio vaccine, in contrast, is less effective at preventing polio but carries no risk of paralysis. ${ }^{137}$ Of course, polio itself can also cause paralysis and death, and so long as poliovirus circulated in the United States, the risk of paralysis from the oral vaccine "was certainly outweighed by the much larger risk for paralysis from wild polioviruses ...."138 However, successful vaccination programs have eradicated wild poliovirus from the Western Hemisphere since 1991. As a result, given the greatly reduced risk of contracting polio itself, in 2000 the CDC's Advisory Committee on Immunization Practices recommended that public health officials eliminate the risk of vaccine-caused paralysis by switching to the inactivated polio vaccine. ${ }^{139}$

The contemporary Anti-Vaxxer Movement, in contrast, represents an illegitimate shift in risk perception and hence an example of the regulatory shifting baseline syndrome, particularly with respect to measles. This syndrome manifests in personal decisions not to vaccinate based on incorrect or exaggerated perceptions of risk to personal health from the vaccines themselves, particularly childhood vaccines, often coupled with assertions of individual liberty or religious rights. However, this shift in risk perception and personal unwillingness to participate in vaccination programs has been possible on a large scale only because of the very success of 20th-century vaccination programs and requirements - that is, because at least two generations of Americans have had the luxury of forgetting what it is like to live with the constant threat of contracting and dying from last century's dread diseases. As a result of that generational amnesia, however, the diseases in question - especially measles - are starting to return.

\section{B. Vaccination Regulation in the U.S. into the Late 20th Century}

Immunization practices have existed since the 18th century, when English physician Edward Jenner used cowpox to inoculate patients against smallpox. ${ }^{140}$ Louis Pasteur added the human rabies vaccine in 1885, along with the concept of virus attenuation, ${ }^{141}$ which allows humans to develop an effective immune response to the disease without contracting the disease itself. Polio, diphtheria, tetanus, and

${ }^{136}$ Malone \& Hinman, supra note 129, at 264.

${ }^{137}$ Id.

${ }^{138} \mathrm{Id}$.

${ }^{139} \mathrm{Id}$.

140 Stephanie F. Cave, The History of Vaccinations in the Light of the Autism Epidemic, 14 Alternative THERAPIES 54, 54 (2008).

${ }^{141} I d$. 
pertussis vaccines followed by 1946, but injectable vaccines were not invented until $1955 .{ }^{142}$

With this last invention, vaccination programs backed by public health regulatory regimes became important public health initiatives in the United States from the mid-20th century. ${ }^{143}$ Since the inception of these vaccination programs, "scientists [have] widely consider[ed] immunization to be one of the greatest public health achievements of the 20th century, and experts and medical science and research agree that timely immunization is vital to staying healthy." 144

\section{Federal Vaccination Programs}

The federal contribution to immunization most often consists of financing programs that make widespread vaccination cheap or free. For example, the first federal vaccination program targeted polio, ${ }^{145}$ and the Poliomyelitis Vaccination Assistance Act of $1955^{146}$ spurred free mass vaccination by providing federal funds to states to pay for the vaccines. ${ }^{147}$ The Act also allowed the Surgeon General to initiate federal polio vaccination delivery, as well. ${ }^{148}$

The federal government continues to financially support vaccination programs, especially childhood vaccination programs, on a significant scale. Most notably:

Since 1962, the federal government has supported childhood vaccination programs through a grant program administered by the CDC. These "317" grants, named for the authorizing statute, support purchase of vaccine for free administration at local health departments and support immunization delivery, surveillance, and communication and education. ${ }^{149}$

Between these 317 grants and the 1994 Vaccines for Children program (discussed below), "[a]s of 2000 , the CDC purchased over half the childhood vaccine administered in the United States ...." $" 150$

\section{2. $\quad$ State Vaccination Requirements for School Attendance}

a. State Authority to Require Vaccines

${ }^{142} \mathrm{Id}$.

${ }^{143} \mathrm{Id}$.

144 IVaccinate, Vaccines Are Effective, Mich. Dept. Health \& Human Servs. (2019), https://ivaccinate.org/about-vaccines/vaccines-are-effective/

${ }^{145} \mathrm{Id}$.

${ }^{146}$ Act of August 12, 1955, Pub. L. No. 377, 69 Stat. 704.

${ }^{147} \mathrm{Id}$. § § 3-6.

${ }^{148} I d . \S 7$.

${ }^{149}$ Malone \& Hinman, supra note 129, at 268.

${ }^{150} \mathrm{Id}$. 
The key regulatory component of vaccine program efficacy in the United States are state requirements that children be vaccinated before they can attend public schools, and often also private schools and daycare facilities. ${ }^{151}$ Massachusetts enacted the first law mandating vaccination in 1809, then enacted the first school vaccination requirement in the 1855 "to prevent smallpox transmission in schools." ${ }^{152}$ In 1905, in Jacobson v. Massachusetts, ${ }^{153}$ the U.S. Supreme Court upheld Massachusetts' (and other states') authority to mandate vaccinations, removing federal constitutional Due Process obstacles to state vaccination laws. Specifically, the Court acknowledged that states have broad police power authority to protect public health ${ }^{154}$ and that Jacobson's Fourteenth Amendment liberty protections did not insulate him from those requirements:

the liberty secured by the Constitution of the United States to every person within its jurisdiction does not import an absolute right in each person to be, at all times and in all circumstances, wholly freed from restraint. There are manifold restraints to which every person is necessarily subject for the common good. On any other basis organized society could not exist with safety to its members. Society based on the rule that each one is a law unto himself would soon be confronted with disorder and anarchy. Real liberty for all could not exist under the operation of a principle which recognizes the right of each individual person to use his own, whether in respect of his person or his property, regardless of the injury that may be done to others. ${ }^{155}$

Moreover, "Upon the principle of self-defense, of paramount necessity, a community has the right to protect itself against an epidemic of disease which threatens the safety of its members." 156

Seventeen years later, the U.S. Supreme Court explicitly addressed the City of San Antonio, Texas's school vaccination mandate in Zucht v. King. ${ }^{157}$ Unlike in Jacobson, there was no imminent threat of contagious disease in San Antonio; nevertheless, public officials barred Rosalyn Zucht from attending both public and private schools because she did not have the required vaccination certificate and

151 State Vaccination Requirements, CENTERS FOR DiseAse CONTROL \& PREVENTION (last updated Nov. 15, 2016), https://www.cdc.gov/vaccines/imz-managers/laws/state-reqs.html; see also Malone \& Hinman, supra note 129, at 269 ("School vaccination laws have played a key role in the control of vaccine-preventable diseases in the United States.").

152 Malone \& Hinman, supra note 129, at 269, 271 (citation omitted).

153197 U.S. 11 (1905). For the story of how resistance to smallpox vaccine mandates and the fiveyear stretch of smallpox epidemics that started in 1900 led to this Supreme Court case, see generally Michael Willrich, Pox: An American Story (Penguin ed. 2012).

154 Jacobson, 197 U.S. at 24-25.

${ }^{155} \mathrm{Id}$. at 26.

${ }^{156} \mathrm{Id}$. at 27.

157260 U.S. 174 (1922). 
refused to get vaccinated. ${ }^{158}$ Relying on Jacobson, the Court found against Zucht in three paragraphs, concluding that "it is within the police power of a state to provide for compulsory vaccination" and "that a state may, consistently with the federal Constitution, delegate to a municipality authority to determine under what conditions health regulations shall become operative." 159

\section{b. The Eventual Universality of School Vaccination Mandates}

By the beginning of the twentieth century, when the Court was considering Jacobson, "nearly half the states had requirements for children to be vaccinated before they entered school. By 1963, when the measles vaccine became available, $\left[{ }^{160}\right] 20$ states, the District of Columbia, and Puerto Rico had such laws, with a variety of vaccines being mandated."161

Measles became a critical focus in the expansion of state vaccination mandates in the later 1960s, as the United States sought to eradicate that disease, and " $[\mathrm{t}] \mathrm{hese}$ experiences demonstrated that mandatory vaccination could be enforced and was effective."162 In 1977, public health officials pursued a nationwide Childhood Immunization Initiative to increase measles vaccination levels in children to 90 percent by 1979, an effort that induced even more states to enact and enforce school vaccination requirements. ${ }^{163}$

School vaccination requirements, when strictly enforced, are quite effective in preventing disease. ${ }^{164}$ As a result, "[b]y the 1980-1981 school year, all 50 states had laws covering students first entering school," 165 by 1983 all 50 states required measles vaccinations, ${ }^{166}$ and "[a]s of the 1998-1999 school year, all states but four (Louisiana, Michigan, South Carolina, and West Virginia) had requirements covering all grades from kindergarten through 12th grade." 167 By that point, "[t]he requirements covered diphtheria toxoid and polio, measles, and rubella vaccines in all 50 states; 49 states required tetanus toxoid, 46 required mumps vaccine, 44 required pertussis vaccine, and 28 required hepatitis B vaccine." 168 In 2000, the Task Force on Community Preventive Services, an independent body that evaluates the effectiveness of public health preventive interventions, recommended the use

\footnotetext{
${ }^{158} \mathrm{Id}$. at 175 .

${ }^{159} \mathrm{Id}$. at 176 (citations omitted).

${ }^{160}$ Malone \& Hinman, supra note 129, at 271.

${ }^{161}$ Id. at 269 (citation omitted).

${ }^{162} \mathrm{Id}$. at 269 (citations omitted).

${ }^{163} \mathrm{Id}$. (citations omitted).

${ }^{164}$ Id. at 270 (citation omitted).

${ }^{165} \mathrm{Id}$. at 270 (citation omitted).

${ }^{166} I d$. at 271 (citation omitted).

${ }^{167} I d$. (citations omitted).

${ }^{168}$ Id. (citations omitted).
} 
of mandatory vaccination requirements to drastically reduce the incidence of vaccine-preventable diseases. ${ }^{169}$

\section{Initial Signals of a Regulatory Shifting Baseline Syndrome: Vaccine Lawsuits, the Childhood Vaccine Injury Act of 1986, and State Vaccine Exemptions}

1. Vaccine Litigation and the National Childhood Vaccine Injury Act of 1986

No vaccine is risk-free, ${ }^{170}$ even when properly manufactured and administered. ${ }^{171}$ As noted, the oral polio vaccine can cause paralysis. ${ }^{172}$ More commonly, the person getting vaccinated faces risks of some sort of immune reaction, ranging from redness and soreness at the vaccine site to a severe allergic reaction that leads to anaphylactic shock and death. ${ }^{173}$

In the United States currently, the initial regulatory regime to balance these risks personal harm against a new vaccine's effectiveness in protecting public health is the Food \& Drug Administration's (FDA's) evaluation pursuant to the drug provisions of the federal Food, Drug, and Cosmetic Act (FDCA). ${ }^{174}$ The federal government has been regulating vaccines since the passage of the 1902 Biologics Control Act, ${ }^{175}$ which gave authority to the Marine Health Service's Laboratory of Hygiene (transformed in 1930 into the National Institutes of Health) authority to regulate vaccines for safety, purity, and potency. ${ }^{176}$ "The Laboratory established standards and licensed smallpox and rabies vaccines," then in 1934 added standards for efficacy. ${ }^{177}$

Although Congress enacted the Food, Drug, and Cosmetic Act in $1938,{ }^{178}$ the FDA did not have authority over vaccines until 1972, when "the Division of Biologics Standards was moved from the National Institutes of Health to the

169 Id. (citing Task Force on Community Preventive Services, Recommendations regarding interventions to improve vaccination coverage in children, adolescents, and adults, 18 AMER. J. Preventive Med. 92, 92-96 (2000)).

${ }^{170}$ Malone \& Hinman, supra note 129, at 273.

${ }^{171}$ Mary Beth Neraas, Comment, The National Childhood Vaccine Injury Act of 1986: A Solution to the Vaccine Liability Crisis?, 63 WASH. L. REV. 149, 149 (1988) (citations omitted).

${ }^{172} \mathrm{Id}$. at 150 .

173 National Vaccine Injury Compensation Program, HeAlth ResourCes \& SeRVS. Admin., last reviewed Jan. 2021, https://www.hrsa.gov/vaccine-compensation/index.html

17421 U.S.C. $\$ \S 301-399$ a.

175 Linda Bren, The Road to the Biotech Revolution-Highlights from 100 Years of Biologics Regulation. FDA CONSUMER 1, 1 (2006), available at https://www.fda.gov/files/about\%20fda/published/The-Road-to-the-Biotech-Revolution--

Highlights-of-100-Years-of-Biologics-Regulation.pdf; Julie B. Milstein, Regulation of vaccines: strengthening the science base, 25 J. PUBLIC HEALTH POL'Y 173, 174 (2004).

${ }^{176}$ Milstein, supra note 175175 , at $174,176$.

${ }^{177} \mathrm{Id}$. at 176.

${ }^{178}$ Act of June 25, 1938, 52 Stat. 1040, codified as 21 U.S.C. $\S \S 301-399$ gg. 
FDA." ${ }^{179}$ The FDCA drug approval regime has received more public attention than normal during the coronavirus pandemic, but a concise overview is still helpful. Under the Act, a "drug" includes any article "intended for use in the diagnosis, cure, mitigation, treatment, or prevention of disease" in humans. ${ }^{180}$ Since 1962, the FDCA has prevented the introduction of any new drug in the United States without the FDA's approval, ${ }^{181}$ which since 1972 has include vaccines. ${ }^{182}$ To get that approval, the manufacturer must prove that a new vaccine is both safe and effective. ${ }^{183}$

However, drug and vaccine "safety" is not absolute but instead requires the FDA to assess whether the benefits of the drug outweigh its risks, a calculus that depends on many factors and under which the FDA might be willing to tolerate more individual risks and side effects if the vaccine prevents a particularly deadly or novel disease. ${ }^{184}$ Any patient who has received warnings about contraindications and side effects from their doctor or pharmacy in connection with a prescription, flu vaccine, or now the new coronavirus vaccines has experienced firsthand the practical results of FDA risk-benefit balancing.

Thus, individual risks usually remain for even the most important and effective vaccines. One of the first signs that members of the U.S. public were beginning to reject the public-oriented focus of vaccination programs ${ }^{185}$ were the products liability torts lawsuits against vaccine manufacturers beginning in the 1950s and escalating through the $1980 \mathrm{~s}$, ${ }^{186}$ seeking personal injury damages for those individuals that vaccines harmed. These lawsuits began with the Cutter Incident, in which Cutter Laboratories released lots of the Salk polio vaccine in which the virus had not been properly inactivated despite the fact that Cutter followed federally mandated manufacturing procedures. About 200 people were paralyzed and ten people died as a result of contracting polio from vaccines from these lots. In 1955, the California Court of Appeals upheld a jury verdict that Cutter Laboratories was liable in tort for these injuries under implied warranty theories, despite the fact that the jury explicitly found that Cutter had not been negligent in producing the

\footnotetext{
179 Milstein, supra note 175 , at 177.

18021 U.S.C. $\$ 321(\mathrm{~g})(1)$ (emphasis added).

${ }^{181}$ Id. $\S 355(\mathrm{a})$.

182 Milstein, supra note 175175 , at 177.

18321 U.S.C. $\$ 355($ b).

${ }^{184}$ See id. $\$ 355-1(\mathrm{a})(1)$ (laying out the risk-benefit analysis and many of the factors to consider).

${ }^{185}$ Miles E. Coleman, An Overview of the National Childhood Vaccination Act, 21 S.C. Lawyer 40, 40 (2010) ("Throughout the 20th century, as vaccination schedules prescribed more and earlier immunizations, there was a growing awareness of the potential dangers of vaccinations and an accompanying resistance to immunization. In response, Congress passed the National Childhood Vaccine Injury Act of 1986").

186 Neraas, supra note 171, at 151 ("Lawsuits against manufacturers rose from 24 in 1980 to approximately 150 in 1985.’).
} 
vaccine. ${ }^{187}$ The proverbial tort floodgates had been opened, and vaccine litigation threatened to leave the United States without vaccine manufacturers. ${ }^{188}$

Responding to this "vaccine liability crisis that has threatened the nation's supply of childhood vaccines," 189 Congress intervened with National Childhood Vaccine Injury Act of 1986 (NCVIA), which established the National Vaccine Injury Compensation Program (VICP). ${ }^{190}$ This program provides compensation to the patients who are injured by listed vaccines ${ }^{191}$ while insulating vaccine manufacturers from tort liability, ${ }^{192}$ ensuring that vaccines remain available to the population at large. A person who receives a covered vaccine and suffers a recognized injury therefrom ${ }^{193}$ files a petition for recovery in the U.S. Court of Federal Claims, ${ }^{194}$ receiving compensation as the Act allows. ${ }^{195}$ According to the U.S. Department of Justice, "Over the past 30 years, the VICP has succeeded in providing a less adversarial, less expensive, and less time-consuming system of recovery than the traditional tort system that governs medical malpractice, personal injury, and product liability cases. More than 6,000 people have been paid in excess of $\$ 3.9$ billion (combined) since the Program's 1988 inception," and "costly litigation against drug manufacturers and health care professionals who administer vaccines has virtually ceased."196

\section{Exemptions from State Vaccination Mandates}

a. Increasing Numbers of State Exemptions from School Vaccination Requirements

The NCVIA ensured that childhood vaccines remained available in the United States. Nevertheless, changes to state vaccination requirements increasingly allowed anti-vaxxers to pursue their individual personal inclinations, allowing disease like measles to re-emerge.

\footnotetext{
${ }^{187}$ Gottsdanker v. Cutter Laboratories, 6 Cal. Rptr. 320, 322-24 (Cal. App. 1st Dist. 1955).

188 Vaccine Injury Compensation Programs, ColL. PhysiCians PhiladelPHiA, as updated Jan. 17, 2018, https://www.historyofvaccines.org/content/articles/vaccine-injury-compensation-programs; see also Neraas, supra mote 171, at 152 ('Between 1966 and 1977, half the nation's vaccine manufacturers stopped producing and distributing vaccines. By 1985, only four commercial firms produced and distributed the primary vaccines used in compulsory vaccination programs.").

${ }^{189}$ Neraas, supra note 171, at 149.

19042 U.S.C. $\S \S 300 \mathrm{aa}-10$ to $300 \mathrm{aa}-23$.

${ }^{191}$ Id. $\S \S 300 \mathrm{aa}-10(\mathrm{a}), 300 \mathrm{aa}-11(\mathrm{c}), 300 \mathrm{aa}-13(\mathrm{a})$.

192 Id. § 300aa-22(b)(1); Bruesewitz v. Wyeth LLC, 562 U.S. 223, 232-33 (2011) (holding that the NCVIA preempts state tort law design defect claims).

19342 U.S.C. $\S 300$ aa- 14.

${ }^{194} I d$. $\S 300 \mathrm{aa}-11$.

${ }^{195}$ Id. $\S 300 \mathrm{aa}-15$.

196 Vaccine Injury Compensation Program, U.S. DEPT. OF JUSTICE (updated Sept. 24, 2018), https://www.justice.gov/civil/vicp.
} 
Exemptions from state vaccination requirements have been part of the legal vaccination landscape almost from the beginning. Even in the 19th century, for example, Massachusetts' vaccination laws allowed "an exception in favor of 'children who present a certificate, signed by a registered physician, that they are unfit subjects for vaccination." "197 Medical exemptions from vaccination continue to find support among public health officials, because "[s]ome people have medical conditions that increase the risk for adverse effect, and therefore they should not receive vaccines. Recognizing this fact, all state vaccination laws provide for exemptions for persons with contraindicating conditions." 198 Utah's medical exemption is fairly typical. While Utah requires students to have a certificate of immunization to attend any "public, private, or parochial kindergarten, elementary, or secondary school through grade 12, nursery school, licensed day care center, child care facility, family care home, or head-start program," 199 children can avoid this requirement if they have a physician's certification that a health condition prevents the child from receiving the vaccine. ${ }^{200}$

The two other exemptions that emerged in states over time-exemptions for religious reasons and exemptions based on personal philosophy - are far less wellgrounded in medicine but instead seek to accommodate other, individual, values. The policy and legal issue they raise for contemporary society and the resurgence of diseases like measles is whether these personal exemptions should trump the greater public good.

\section{b. Personal Philosophical Exemptions from Vaccine Requirements}

Personal philosophical exemptions from vaccination requirements allow parents to avoid the school vaccination requirements for their child on the basis of personal or moral beliefs. ${ }^{201}$ These exemptions originated in the British Vaccination Act of 1898, which "provided a conscience clause to allow exemptions to mandatory smallpox vaccination. This clause gave rise to the term "conscientious objector,' which later came to refer to those opposed to military service."202 Philosophic objections to mandatory vaccination can hark back to Jacobson's objection to this basic infringement on liberty, arise from a fear of an adverse reaction to or contamination from the vaccines, or reflect the parents' conclusions

\footnotetext{
197 Jacobson, 197 U.S. at 12 (citing MASs. REV. L. chap. 75, § 139). Massachusetts added its medical exemption in 1894. Douglas S. Diekema, Personal Belief Exemptions for School Vaccination Requirements, 35 AnN. Rev. Pub. Health 275, 278 (2014), https://doi.org/10.1146/annurevpublhealth-032013-182452.

${ }^{198}$ Malone \& Hinman, supra note 129, at 273.

199 UTAH CODE ANN. § 53A-11-301 (2020).

${ }^{200} I d$. $§ 53 \mathrm{~A}-11-302$.

201 States With Religious and Philosophical Exemptions From School Immunization Requirements, NATl. Conf. State Legislatures (Jan. 29, 2021), https://www.ncsl.org/research/health/schoolimmunization-exemption-state-laws.aspx

202 Vaccination Exemptions, HISTORY OF VACCINES (updated Jan. 7, 2018), https://www.historyofvaccines.org/index.php/content/articles/vaccination-exemptions.
} 
that their children really aren't at risk of contracting particular diseases or that the diseases for which vaccinations are required really aren't that bad. ${ }^{203}$

States were actively adopting philosophical exemptions between 1970, when only "five state allowed exemption from the law if a parent simply objected in writing," 204 and 2014. By the beginning of 21 st century, 15 states provided exemptions for personal philosophical objections - California, Colorado, Idaho, Louisiana, Maine, Michigan, Minnesota, New Mexico, North Dakota, Ohio, Oklahoma, Utah, Vermont, Washington, and Wisconsin. ${ }^{205}$ By 2014, the number had risen to 22, subtracting New Mexico but adding Arizona, Arkansas, Missouri (childcare facilities only), Oregon, Pennsylvania, Texas, Virginia (HPV vaccine only), and Wisconsin. ${ }^{206}$ Moreover, use of these exemptions more than doubled. ${ }^{207}$

States phrase these exemptions a variety of ways. Harkening back to England, Texas allows the exemption if a parent cites "reasons of conscience." 208 Arizona, in turn, requires that:

The parent or guardian of the pupil submits a signed statement to the school administrator stating that the parent or guardian has received information about immunizations provided by the department of health services and understands the risks and benefits of immunizations and the potential risks of nonimmunization and that due to personal beliefs, the parent or guardian does not consent to the immunization of the pupil. ${ }^{209}$

Despite their early 21 st-century popularity, however, states can easily eliminate philosophical exemptions. As Jacobson and Zucht make clear, these exemptions exist purely as a matter of the state's largesse, politically accommodating parents who prefer not to vaccinate their children, often as a result of unwarranted concerns about the vaccines.

\footnotetext{
203 Malone \& Hinman, supra note 129, at 273.

204 Diekema, supra note 197, at 279

205 Malone \& Hinman, supra note 129, at 273.

206 This list combines information from States With Religious and Philosophical Exemptions From School Immunization Requirements, NATl. Conf. State Legislatures (Jan. 29, 2021), https://www.ncsl.org/research/health/school-immunization-exemption-state-laws.aspx, with that web site's prior incarnation, States With Religious and Philosophical Exemptions From School Immunization Requirements, Natl. Conf. State Legislatures (June 26, 2020), https://www.ncsl.org/research/health/school-immunization-exemption-state-laws.aspx. See also Vaccination Exemptions, HISTORY OF VACCINES (updated Jan. 7, 2018), https:/www.historyofvaccines.org/index.php/content/articles/vaccination-exemptions (also counting 20 states before California's and Vermont's changes in 2015).

207 Vaccination Exemptions, HISTORY OF VACCINES (updated Jan. 7, 2018), https://www.historyofvaccines.org/index.php/content/articles/vaccination-exemptions.

${ }^{208}$ TEX. Edu CODE ANN. $§ 38.001$.

${ }^{209}$ ARIZ. REV. StAT. ANN. § 15-873(A)(1).
} 


\section{c. Religious Exemptions from Vaccine Requirements}

State exemptions from vaccine requirements for religious reasons are both more pervasive and potentially more legally and politically difficult to remove, given the Free Exercise Clause in the First Amendment to the U.S. Constitution. ${ }^{210}$ The Christian Science Church was particularly active in lobbying for religious exemptions in the 20th century, and by 1970 "most states allowed exemption from school vaccine requirements ... if the parents could demonstrate that the vaccination would violate the teachings of a recognized religious organization to which they belonged ...."211

The U.S. Supreme Court has never squarely addressed whether the First Amendment - or, since 1993, the Religious Freedom Restoration Act $^{212}$-requires a religious exemption from mandatory vaccination laws. Indeed, it has signaled just the opposite: when offered the opportunity, the Court has gone out of its way to suggest that vaccine mandates are insulated from claims of religion freedom. For example, its 1944 case of Prince v. Massachusetts addressed the issue of whether a Jehovah's Witness could violate child labor laws on religious grounds. ${ }^{213}$ Along the way to upholding Massachusetts' conviction of the parent, the Court emphasized that:

neither rights of religion nor rights of parenthood are beyond limitation. Acting to guard the general interest in youth's well being, the state as parens patriae may restrict the parent's control by requiring school attendance, regulating or prohibiting the child's labor, and in many other ways. ... Thus, he cannot claim freedom from compulsory vaccination for the child more than for himself on religious grounds. The right to practice religion freely does not include liberty to expose the community or the child to communicable disease or the latter to ill health or death. ${ }^{214}$

\footnotetext{
${ }^{210}$ U.S. CONST., amend. I.

211 Diekema, supra note 197, at 279.

21242 U.S.C. $\S 2000$ bb et seq.

213321 U.S. 158, 159-60 (1944).

${ }^{214}$ Id. at 166-67 (citations omitted; emphasis added). Indeed, even in 1972 in one of the most important cases upholding religious freedom against state schooling requirements, the Supreme Court still emphasized that the case was "not one in which any harm to the physical or mental health of the child or to the public safety, peace, order, or welfare has been demonstrated or may be properly inferred," again insulating the decision from directly intruding into public health mandates. Wisconsin v. Yoder, 406 U.S. 205, 230 (1972). Moreover, the U.S. Courts of Appeals recently have nearly uniformly upheld vaccine mandates against religious freedom claims. See, e.g., Fallon v. Mercy Catholic Medical Center of Southeastern Pennsylvania, 877 F.3d 487, 492-93 (3rd Cir. 2017) (holding that a hospital worker's refusal to comply with a flu vaccination requirement did not give rise to a religious discrimination claim and noting that "that we are not the only court to come to the conclusion that certain anti-vaccination beliefs are not religious"); Phillips v. City of New York, 775 F.3d 538, 542-44 (2d Cir. 2015) (upholding New York's application of its religious exemption
} 
Seventy years later, in 2014, a very different Court displayed the same reluctance to subject vaccination mandates (or, more technically, requirements that medical insurance cover the vaccinations) to the vagaries of individual religious beliefs. In Burwell v. Hobby Lobby Stores, Inc., the Court determined that federal mandates in the Affordable Care Act requiring that employers provide health insurance that covers contraception, to which the employers involved objected on religious grounds, violate the Religious Freedom Restoration Act. ${ }^{215}$ While the case had nothing directly to do with vaccination, along the way to its decision (prompted by the Department of Health and Human Services), the Court majority made clear that its decision did not necessarily extend to vaccines:

Our decision should not be understood to hold that an insurancecoverage mandate must necessarily fall if it conflicts with an employer's religious beliefs. Other coverage requirements, such as immunizations, may be supported by different interests (for example, the need to combat the spread of infectious diseases) and may involve different arguments about the least restrictive means of providing them. ${ }^{216}$

Even the Supreme Court's most recent coronavirus-related religious freedom case, Roman Catholic Diocese of Brooklyn v. Cuomo, ${ }^{217}$ does not necessarily subject vaccination requirements to constitutional or statutory claims of religious freedom. The case upheld a religious freedom First Amendment challenge to the New York Governor's executive order limiting religious services in "red" and "orange" zones to 10 and 25 attendees, respectively. ${ }^{218}$ The Court emphasized that the executive order imposed no such crowding limitations on "essential" businesses like liquor and hardware stores, nor did it tailor attendance limitations to the size of the church or synagogue, ${ }^{219}$ constitutionally suspect differentiations that a vaccination mandate is unlikely to make. In addition, Justices Breyer,

against challenges from parents seeking exemptions on non-religious grounds); Caviezel v. Great Neck Public Schools, 500 Fed. Appx. 16, 18-19 (2d. Cir. 2012) (upholding a New York denial of a religious exemption); Workman v. Mingo Co. Bd. Education, 419 Fed. Appx. 348, 354-56 (4th Cir. 2011) (upholding West Virginia's lack of a religious exemption).

215573 U.S. 682, 736 (2014).

${ }^{216}$ Hobby Lobby, 573 U.S. at 733 (emphasis added. In addition, as the Court explained at length, the application of the Religious Freedom Restoration Act to state mandates created a separate set of constitutional issues, leading to the Court invalidating Congress's original attempt to do so pursuant to the Fourteenth Amendment. Id. at 693-96 (explaining City of Boerne v. Flores, 521 U.S. 507 (1997)).

217 --- U.S. --- 114 S. Ct. 63 (2020).

${ }^{218}$ Id. at 66.

${ }^{219} \mathrm{Id}$. at 66-67. 
Sotomayor, and Kagan dissented on the merits regardless, ${ }^{220}$ and both Justices Gorsuch and Kavanaugh, who voted in the majority, wrote concurring opinions that suggest that they might see a vaccination case differently-Justice Gorsuch explicitly suggesting that the vaccine requirement in Jacobson might survive strict scrutiny, ${ }^{221}$ Justice Kavanaugh emphasizing the "substantial deference" owed to state policy choices during pandemics. ${ }^{22}$

In the few cases that exist, State supreme Court explicitly ruled against religious freedom claims and upheld vaccine mandates. ${ }^{223}$ Indeed, the Mississippi Supreme Court went so far as to strike down the legislature's attempted religious exemption on grounds that it violated the Fourteenth Amendment's Equal Protection Clause. ${ }^{224}$ Tipping its hand, it first asked, "Is it mandated by the First Amendment to the United States Constitution that innocent children, too young to decide for themselves, are to be denied the protection against crippling and death that immunization provides because of a religious belief adhered to by a parent or parents?" 225 The specter of children suffering "the horrors of crippling and death resulting from poliomyelitis or smallpox or from one of the other diseases against which means of immunization are known and have long been practiced successfully" haunts the rest of the opinion. ${ }^{226}$

Nevertheless, despite the apparent lack of constitutional or statutory requirement, the vast majority of states avoided Mississippi's haunting. By the beginning of the 21 st century, 48 states - all but Mississippi and West Virginiaallowed exemptions from mandatory school vaccination requirements on religious grounds. $^{227}$

\section{d. Correlations Between Exemptions and Reduced Vaccination Rates}

The non-medical exemptions from state school vaccination requirements allowed Anti-Vaxxers considerable latitude to exercise their individual choiceswith consequences to public health. To be sure, into the 21 st century nationwide vaccination rates remained high. ${ }^{228}$ Nevertheless, of the seven states where more than $1 \%$ of students used exemptions in the 1997-1998 school year, fourColorado, Michigan, Utah, and Washington-had philosophical exemptions. ${ }^{229}$

\footnotetext{
${ }^{220} I d$. at 76-78 (Breyer, J., dissenting). Chief Justice Roberts dissented on grounds of mootness. Id. at 75-76 (Roberts, C.J., dissenting).

${ }^{221} I d$. at 71 (Gorsuch, J., concurring).

${ }^{222} \mathrm{Id}$. at 73-74 (Kavanaugh, J., concurring.

${ }^{223}$ E.g., Wright v. DeWitt School Dist., 385 S.W.2d 644, 648 (Ark. 1965).

${ }^{224}$ Brown v. Stone, 378 So.2d 218, 233 (Miss. 1979).

$225 \mathrm{Id}$. at 221 .

${ }^{226}$ Id. at 222-23. See also Dalli v. Board of Education, 267 N.E.2d 219, 223 (Mass. 1971) (striking down Massachusetts' religious exemption on Equal Protection grounds because it favored some religions over others).

${ }^{227}$ Malone \& Hinman, supra note 129, at 273.

${ }^{228} \mathrm{Id}$. at 274 (citation omitted).

${ }^{229} \mathrm{Id}$.
} 
Moreover, pockets of non-vaccination began to emerge at the community scale, and "in some communities, the levels of exemptors may be as high as 5\%. In 1995, 84\% of California schools had fewer than $1 \%$ of students with exemptions, but $4 \%$ of schools had 5\% or more with exemptions." 230 The State of Washington, which allows all three kinds of exemptions, had "an overall exemption rate of $5.2 \%$ in the 2014-15 school year." 231 Overall, between the 2011-2012 school year and the 20172018 school, use of non-medical exemptions for school vaccination requirements has continued to increase, with some states seeing the vaccination rates for kindergarteners entering school in Fall 2017 as low as $81.3 \%{ }^{232}$

Starting in the late 1980 s, exemptions from vaccination also increasingly correlated to increased risk of measles, particularly in religious communities, such as the Amish. "Salmon et al. found that persons with documented religious or philosophic exemptions were 35 times more likely to contract measles than were vaccinated persons during 1985-1992. They also found that persons living in communities with high concentrations of exemptors were themselves at increased risk for measles because of increased risk for exposure." 233

Thus, individual choices to seek exemptions from state vaccine mandates fairly quickly began to impact the public health commons as well as the exemptors themselves. It also become clear that legal design was an important factor in individuals' decisions to exploit an exemption: states with complicated processes for obtaining their religious and philosophical exemptions maintained high rates of student vaccination, while one-third of the states with simple procedures had their exemption rates exceed $1 \%$ of students. ${ }^{234}$

\section{The Regulatory Shifting Baseline Syndrome and Anti-Vaxxers}

\section{Anti-Vaxxers in the United States}

Resistance to vaccination has existed since inoculations were first invented. Indeed, skepticism regarding the efficacy and safety of the earliest inoculation practices was often fully justified, given the state of medical science and rather loose oversight of practitioners at the time. ${ }^{235}$ For example, when smallpox was the disease of biggest concern:

\footnotetext{
${ }^{230} I d$. (citation omitted).

231 Vaccination Exemptions, HistORY OF VACCINES (updated Jan. 7, 2018), https://www.historyofvaccines.org/index.php/content/articles/vaccination-exemptions.

${ }^{232}$ Robert A. Bednarczyk, Adrian R. King, Ariana Lahijani, \& Saad B. Omer, Current landscape of nonmedical vaccination exemptions in the United States: Impact of Policy changes, 18 EXPERT REV. VACCINES 175, 178 (2019), https://doi.org/10.1080/14760584.2019.1562344.

${ }^{233}$ Id. (citations omitted; emphasis added).

${ }^{234} \mathrm{Id}$.

235 The anti-vaccination movement, MEASLES \& Rubella InITIATIVE (viewed Jan. 27, 2021), https://measlesrubellainitiative.org/anti-vaccination-movement/.
} 
In the late 1800s through the early 1900s, some parents responded to school vaccination laws by refusing to send their children to school, sending their children to private schools, wiping the vaccine from their children's arms following vaccination, attempting to fake vaccine scars, and refusing to comply with vaccination requirements. This resistance was driven in part by the risks of the smallpox vaccine and the risks of inoculation, which included the transmission of other diseases, including tetanus.... Opposition to vaccination became stronger during the early 1900s when a milder form of smallpox, variola minor, became the dominant strain. This strain rarely caused death, leading many to conclude that the vaccine was more dangerous than the disease it prevented. ${ }^{236}$

The United States, however, has a long history of vaccine resistance rooted in issues other than legitimate concerns about the safety and efficacy of the vaccines themselves. ${ }^{237}$ Many religions and religious leaders, for example, have actively discouraged vaccination: "fear of vaccines emerged in the 18th century. Religious figureheads often referred to them as 'the devil's work' and actively spoke against them." ${ }^{238}$ Racism and racial mistrust have played a role in vaccination resistance. ${ }^{239}$ Personal liberty objections have also long been important in both England and the United States. For example, when England enacted the Vaccinated Act in 1853, requiring vaccination against smallpox for infants up to three months old and mandating penalties for noncompliance, several organizations formed to resist the new mandate, including London's Anti-Vaccination League. ${ }^{240}$ In the United States, opposition to vaccination mandates reflected uneasiness over the increasing intrusion of government into private lives, arguably constituting one of the first civil liberty struggles. ${ }^{241}$ "Parents also protested on the grounds that vaccination threatened the safety of their children, usurped their parental authority, and violated the bodily integrity of their children." 242

Current opposition to vaccines in the United States is generally categorized into two levels of severity. Some people are still resistant to vaccinating themselves and their children. This resistance is known as "vaccine hesitancy," and it affects "motivation, causing people to reject it for themselves or their children...[leading

\footnotetext{
236 Diekema, supra note197, at 278 (citations omitted).

237 See, e.g., WILLRICH, supra note 153, at 12 (noting that "reasonable health concerns do not alone explain the widespread opposition to compulsory vaccination at the turn of the twentieth century.").

238 Olivia Benecke \& Sarah Elizabeth DeYoung, Anti-Vaccine Decision-Making and Measles Resurgence in the United States, 6 Global Pediatric Health $2333794 X 19862949$ (2019) [online], doi: 10.1177/2333794X19862949. See also WILlRICH, supra note 153, at 12 ("Christian Scientists viewed compulsory vaccination as a violation of religious freedom.”).

239 WILLRICH, supra note 153, at 12.

${ }^{240}$ Id.; The anti-vaccination movement, MEASLES \& RUBELLA INITIATIVE (viewed Jan. 27, 2021), https://measlesrubellainitiative.org/anti-vaccination-movement/.

${ }^{241}$ WILLRICH, supra note 153, at 13-24.

242 Diekema, supra note 197, at 278.
} 
to the] undermine[d] vaccination coverage in specific settings." 243 An "antivaxxer," in turn, is an individual who is outright opposed to vaccinations for various reasons. ${ }^{244}$ These individuals typically associate with the "anti-vaccination movement," or "anti-vaxxer movement," in an effort to prevent the use of vaccines to immunize people from certain contagious illnesses. ${ }^{245}$

With the spectrum of resistance is real, people along the entire spectrum often now find justification for their resistance in misleading and false information that has made the personal risks from the vaccines themselves seem unduly high. For example, "[i]n the 1970s, concern about the possibility of pertussis vaccine causing sudden infant death syndrome or infantile spasms led to debate about pertussis vaccination requirements, even though studies showed that the vaccine caused neither event." 246 Nevertheless, these fears led to an especially substantial expansion of the Anti-Vaxxer Movement in the United Kingdom into the 1980s, "when parents increasingly refused to vaccinate their children against pertussis in response to a report that attributed 36 negative neurological reactions to the pertussis vaccine. This caused a decrease in the pertussis vaccine uptake in the United Kingdom from $81 \%$ in 1974 to $31 \%$ in 1980 , eventually resulting in a pertussis outbreak ...."247

\section{Anti-Vaxxers and Measles}

Measles is not the deadliest of infectious diseases. Even so, "Before the introduction of measles vaccine in 1963 and widespread vaccination, major epidemics occurred approximately every 2-3 years and measles caused an estimated 2.6 million deaths each year." ${ }^{248}$ World population in 1963 was a little over 3.211 billion people, ${ }^{249}$ meaning that roughly one out of every 1235 individuals on the planet died from measles every year. In contrast, the rate of severe allergic reactions to the MMR (mumps-measles-rubella) vaccine is about one in 1 million doses. ${ }^{250}$ It was thus roughly 1000 times less risky to get the

\footnotetext{
${ }^{243}$ World Health Organization, Improving vaccination demand and addressing hesitancy, World Health Organization (June 17, 2020), http://awareness.who.int/immunization/programmes_systems/vaccine_hesitancy/en/.

${ }^{244}$ Thomas Keegan \& Rhiannon Edge, It's wrong to assume that the choice not to vaccinate is always down to ignorance, THE CONVERSATION (Sept. 16, 2016). https://theconversation.com/itswrong-to-assume-that-the-choice-not-to-vaccinate-is-always-down-to-ignorance-123112.

245 The anti-vaccination movement, MEASLES \& RUBELla INITIATIVE, https://measlesrubellainitiative.org/anti-vaccination-movement/ (last visited June 24, 2020).

${ }^{246}$ Malone \& Hinman, supra note 129, at 274.

${ }^{247}$ Benecke \& DeYoung, supra note 238.

248 World Health Organization, Measles (5 Dec. 2019), https://www.who.int/news-room/factsheets/detail/measles.

249 World Population by Year, WORLDOMETER, https://www.worldometers.info/worldpopulation/world-population-by-year/ (as viewed Jan. 23, 2021).

${ }^{250}$ Jeanne P. Spencer, Ruth H. Trondsen Pawlowski, \& Stephanie Thomas, Vaccine Adverse Events: Separating Myth from Reality, 95 Amer. FAMily Physician 786, 787 tbl. 1 (2017).
} 
measles vaccine than to walk around unvaccinated even in just the year of vaccination, let alone over a lifetime.

That calculus has changed. Even in a bad year, measles now causes only about 140,000 deaths globally, ${ }^{251}$ reflecting a reduction in yearly measles deaths since 1963 of over $94 \%$ despite a world population that has more than doubled in the interim. Nevertheless, with the rare exception of a disease like smallpox that now exists only in laboratories, vaccination remains necessary to protect the public commons, as the 2000 polio recommendation suggests and-given its infection rate-remains particularly true for measles.

Anti-Vaxxer resistance to measles vaccines, however, got an unfortunate boost from the false linking of the MMR vaccine to autism, unfortunately given credence "by the 1998 publication of a series of articles in The Lancet by a former British doctor, Andrew Wakefield.." 252 "Despite the small sample size $(n=12)$, the uncontrolled design, and the speculative nature of the conclusions, the paper received wide publicity, and MMR vaccination rates began to drop because parents were concerned about the risk of autism after vaccination." ${ }^{253}$ Recent research indicates that the fraudulent research continues to influence parents' decisions to not vaccinate their children, particularly as the internet and social media become increasingly popular sources of "medical" advice. ${ }^{254}$

Thus, the regulatory baseline for MMR vaccine has illegitimately shifted, and expanded exemptions from state vaccination mandates played a critical role in allowing individual choices to once again endanger public health. ${ }^{255}$ Children (and others) are paying the price.

\section{E. The Resumption of Vaccine Requirements, with a Note on the Coronavirus Pandemic}

Incidents like the Lancet fraud and the low vaccination rates in some states in 2017 illuminate how far the public's risk perception baseline has shifted from the vaccine-preventable diseases to the vaccines themselves, warranting restoration of

${ }^{251}$ World Health Organization, Measles (5 Dec. 2019), https://www.who.int/news-room/factsheets/detail/measles.

${ }^{252}$ Benecke \& DeYoung, supra note 238. The critical paper was Andrew J. Wakefield et al., Ileallymphoid-nodular hyperplasia, non-specific colitis, and pervasive developmental disorder in children, 351 LANCET 637, 637-41 (1998) (retracted by the journal for fraud in March 2010).

${ }^{253}$ T. S. Sathyanarayana Rao \& Chittaranjan Andrade, The MMR vaccine and autism: Sensation, refutation, retraction, and fraud, 53 INDIAN J. PSYCHIATRY 95, 95 (2011), doi: 10.4103/00195545.82529 .

${ }^{254}$ Lucy E Elkin, Susan R.H. Pullon, \& Maria H. Stubbe, 'Should I vaccinate my child?' Comparing the displayed stances of vaccine information retrieved from Google, Facebook and YouTube, 38 VACCINE 2772, 2771 (2020) (citations omitted), https://doi.org/10.1016/j.vaccine.2020.02.041; Benecke \& DeYoung, supra note 238. For a particularly pointed internet response to anti-vaxxer rhetoric, see Rada Jones, 24 reasons not to vaccinate your kid, KEVINMD.COM (Jan. 25, 2020), https://www.kevinmd.com/blog/2020/01/24-reasons-to-not-vaccinate-your-kid.html.

${ }^{255}$ Benecke \& DeYoung, supra note 238; Diekema, supra note 197, at 283-84. 
regulatory regimes' full strength. Fortunately, in the United States, resurgences of diseases thought long vanquished, like measles, have inspired governments to once again strengthen their vaccine programs and requirements, suggesting that disease resurgence is reactivating cultural memory and at least partially correcting this regulatory shifting baseline syndrome.

\section{The Federal Government's Response to Measles Resurgence}

Although vaccination levels in schoolchildren during the 1980 s were $90 \%$ or higher as a result of the new school vaccination requirements, rates among preschool children were significantly lower. ${ }^{256}$ The result was a measles resurgence in 1989-1991, "primarily affecting unvaccinated preschool-aged children," 257 that resulted in 55,000 reported cases. In response, Congress created the Vaccines for Children Program ${ }^{258}$ through the Omnibus Budget Reconciliation Act of 1993. ${ }^{259}$ The program lasted a decade, between 1994 and 2013. Under it "all Medicaideligible children, all children who are uninsured, all American Indian and Alaska Native children, and insured children whose coverage does not include vaccinations (with limitations on the locations where this last group can receive VFC vaccine) qualify to receive routine childhood vaccines at no cost for the vaccine."260

In 2014, the CDC analyzed this program and concluded that it was a rousing success. $^{261}$ Thus, the Vaccines for Children Program indicates that stepped-up federal financing of vaccination can be one effective corrective to Anti-Vaxxer sentiments.

\section{The States' Responses to Measles Resurgence}

Resurgences of diseases like measles have also led some states to re-think their exemptions from school vaccination requirements. In response to the 2014-2015 measles outbreak, for example, several states revisited their vaccination laws. In 2015, "Vermont became the first state to repeal its personal belief exemption," followed by California, which "removed exemptions based on personal beliefs, which are defined in that state as also including religious objections." ${ }^{262}$ Other

\footnotetext{
${ }^{256}$ Malone \& Hinman, supra note 129, at 270.

${ }^{257} \mathrm{Id}$.

258 Cynthia G. Whitney, Fangjun Zhou, James Singleton, \& Anne Schuchat, Benefits from Immunization During the Vaccines for Children Program Era-United States, 1994-2013, Centers for Disease Control \& Prevention Morbidity \& Mortality WeEkly Report (April 25, 2014), https:/www.cdc.gov/mmwr/preview/mmwrhtml/mm6316a4.htm.

${ }^{259}$ Pub. L. No. 103-66, § 13631, 107 Stat. 312 (Aug. 10, 1993), codified at 42 U.S.C. § 1396v.

${ }^{260}$ Malone \& Hinman, supra note 129, at 268.

261 Whitney et al., supra note 258.

${ }^{262}$ States With Religious and Philosophical Exemptions From School Immunization Requirements, Natl. Conf. State Legislatures (June 26, 2020), https://www.ncsl.org/research/health/schoolimmunization-exemption-state-laws.aspx. See also Vaccination Exemptions, HisTORY OF VACCINES
} 
states made it more difficult to claim an exemption from the vaccine requirements - a procedural modification that, as noted above, has been correlated with significantly lower rates of exemption use. For example, Connecticut "require[d] an annual, notarized, statement from parents or guardians specifying religious objection to required vaccinations," while West Virginia amended its vaccine legislation to "require[] certification by a licensed physician for medical exemption requests," and Illinois "require[d] parents or guardians who claim a religious exemption to detail their objections for specific immunizations, obtain a health care provider's signature, and submit an exemption certificate for each child before kindergarten, sixth and ninth grade."263

State amendments to vaccine exemptions have continued. In 2016, both Michigan and Delaware revisited their school vaccine mandates, with Delaware weakening its religious exemption. ${ }^{264}$ In 2017, Indiana required college students living on campus to be immunized against meningitis, while Utah potentially eviscerated parental control by allowing minors to consent to their own vaccinations. ${ }^{265}$

The 2019 measles outbreak again inspired states to strengthen their vaccine requirements, especially New York. As noted above, measles cases in 2019 occurred in 31 states, but " $75 \%$ of cases were linked to outbreaks in New York City and New York state, most of which were among unvaccinated children in Orthodox Jewish communities." 266 In response to these measles outbreaks, New York ended its religious exemption and other exemptions from school vaccine requirements. ${ }^{267}$

State legislatures in Arkansas, Maine, Washington, Colorado, and Virginia also responded to the 2019 measles outbreaks. In fairly targeted legislation, Washington removed "the personal belief exemption for the measles, mumps and rubella vaccine requirement for public schools, private schools and day care centers.." 268 Maine, in contrast, eliminated both its religious and personal belief exemptions, ${ }^{269}$

(updated Jan. 7, 2018), https://www.historyofvaccines.org/index.php/content/articles/vaccinationexemptions (noting Vermont's and California's 2015 law eliminating all non-medical exemptions). ${ }^{263}$ States With Religious and Philosophical Exemptions From School Immunization Requirements, Natl. Conf. State Legislatures (June 26, 2020), https://www.ncsl.org/research/health/schoolimmunization-exemption-state-laws.aspx.

${ }^{264} I d$.

${ }^{265} \mathrm{Id}$.

${ }^{266}$ News Staff, "In Wake of Measles Outbreaks, CDC Updates 2019 Case Totals," AAFP (Oct. 9, 2019), https://www.aafp.org/news/health-of-the-public/20191009measlesupdt.html.

${ }^{267}$ Bobby Allyn, "New York Ends Religious Exemptions for Required Vaccines," NPR (June 13, 2019), https://www.npr.org/2019/06/13/732501865/new-york-advances-bill-ending-religiousexemptions-for-vaccines-amid-health-cris.

268 States With Religious and Philosophical Exemptions From School Immunization Requirements, Natl. Conf. State Legislatures (Jan. 29, 2021), https://www.ncsl.org/research/health/schoolimmunization-exemption-state-laws.aspx (providing the same information).

${ }^{269} \mathrm{Id}$. 
although these changes do not take effect until September 2021. ${ }^{270}$ As of 2019, Arkansas now requires public and private schools to maintain records regarding vaccination exemption use; in 2020, Colorado established similar requirements and requires parents claiming a personal or religious exemption to complete an online education program first. ${ }^{271}$ Finally, in 2020 Virginia required its school vaccination requirements to "be consistent with the Immunization Schedule developed and published by the Centers for Disease Control and Prevention, the Advisory Committee on Immunization Practices, the American Academy of Pediatrics, and the American Academy of Family Physicians."272

Thus, over the course of six years, state legislatures significantly shifted the vaccine regulatory baseline back toward public protection. By January 2021, the number of states with a personal philosophy exemption had dropped back to $15 .{ }^{273}$ A record five states now have no non-medical exemptions, while several others made use of the exemptions more difficult, including through education requirements. ${ }^{274}$ The cultural memory that school vaccination requirements curb personal impulses that put the public health at risk appears to be, for the moment, at least partially re-activated.

\section{Coronavirus Vaccines and the Anti-Vaxxers}

Before COVID-19 locked down the United States in March 2020, the last true pandemic in this country was the $1918 \mathrm{H} 1 \mathrm{~N} 1 \mathrm{flu}$ ("Spanish flu) pandemicalthough the $2009 \mathrm{H} 1 \mathrm{~N} 1 \mathrm{flu}$ ("swine flu") outbreak did considerable damage. ${ }^{275} \mathrm{In}$ 13 months, between January 21, 2020, and February 20, 2021, the coronavirus pandemic had killed over 495,000 people in the United States and over 2.45 million worldwide 276 _levels approaching pre-vaccine death rates from measles. By February 2021, mass vaccinated against the new disease its early stages even as

270 State Vaccination Exemptions for Children Entering Public Schools, ProCon.org (Mar. 4, 2020), https://vaccines.procon.org/state-vaccination-exemptions-for-children-entering-publicschools/.

${ }^{271}$ States With Religious and Philosophical Exemptions From School Immunization Requirements, Natl. Conf. State Legislatures (Jan. 29, 2021), https://www.ncsl.org/research/health/schoolimmunization-exemption-state-laws.aspx (providing the same information).

272 Id.

${ }^{273} \mathrm{Id}$.

${ }^{274} I d$.

275 Worst Outbreaks in U.S. History, Healthline, as viewed Jan. 27, 2021, https://www.healthline.com/health/worst-disease-outbreaks-history. "The CDC estimates that there were 60.8 million cases, 274,304 hospitalizations, and 12,469 deaths in the United States" from the 2009 flu outbreak. Id.

${ }^{276}$ United States COVID-19 Cases and Deaths by State, Centers for Disease Control \& Prevention, as updated Jan. 26, 2021, https://covid.cdc.gov/covid-data-tracker/\#cases totaldeaths. The exact count as of January 26, 2021, was 419,827 deaths, reflecting 1891 new deaths from the previous day. Id. 
public health workers were discovering more virulent mutations of the virus. ${ }^{277}$ Will the vaccine regulatory baseline syndrome affect the United States' ability to effectively combat the pandemic?

Research is mixed as the Article goes to press. On the one hand, early studies indicate significant resistance to taking the new coronavirus vaccines, even among healthcare workers. ${ }^{278}$ Moreover, a 2020 report from the Centre for Countering Digital Hate indicated that, globally, "social media accounts held by socalled anti-vaxxers have increased their following by at least 7-8 million people since 2019" and that "31 million people follow anti-vaccine groups on Facebook." ${ }^{279}$ False and misleading rumors about the two approved COVID-19 vaccines are easy to find on the internet and across social media. ${ }^{280}$ On the other, other studies indicate that, at least in the United States, political affiliation, geographic location, distrust of speedy approval processes and foreign vaccines, and race all appear to be relevant factors in a particular person's reluctance to become vaccinated. ${ }^{281}$ As a result, as coronavirus vaccines roll out, it difficult to assess whether resistance reflects the more general vaccine regulatory shifting baseline syndrome at work, whether resistance to coronavirus vaccines is a specific phenomenon resulting from a particular cultural and political moment that will fade as 2021 and (hopefully) successful vaccination efforts progress, or a little of both.

\section{RECONCEPTUALIZING THE "WATERS OF THE UNITED STATES" CONTROVERSY AS A REgulATORY SHIFTING BASELINE SYNDROME}

Can the regulatory shifting baseline syndrome operate more subtly within statutory regimes to undermine regulatory efficacy? This Part examines the ongoing "waters of the United States" controversy within the federal Clean Water Act to suggest that the answer is "yes."

In 1969, two water pollution events occurred that spurred Congress to increase the federal involvement in water pollution control: the latest in a century-long series

\footnotetext{
277 COVID-19: Emerging SARS-CoV-2 Variants, CENTERS FOR DisEASE CONTROL \& PREVENTION (updated Jan. 28, 2021), https://www.cdc.gov/coronavirus/2019-ncov/more/science-andresearch/scientific-brief-emerging-variants.html

${ }^{278}$ Liji Thomas, Low acceptance of COVID-19 vaccine among healthcare workers in USA, MediCAL News, Jan. 6, 2021, https://www.news-medical.net/news/20210106/Low-acceptance-ofCOVID-19-vaccine-among-healthcare-workers-in-USA.aspx; Stacy Kuebelbeck Paulsen, Who will accept a COVID-19 vaccine?, CENTER FOR InfeCtIOUS DiseASe ReSEARCH \& POL'y (Oct 21, 2020), https://www.cidrap.umn.edu/news-perspective/2020/10/who-will-accept-covid-19-vaccine.

${ }^{279}$ Talha Burki, The onlne anti-vaccine mavement in the age of COVID-19, THE LANCET DiGITAL HEALTH [online] (Oct. 2020), https://doi.org/10.1016/S2589-7500(20)30227-2.

${ }^{280}$ Dennis Thompson, Anti-Vaxxers Wage Campaigns Against COVID-19 Shots, WeBMD (Jan. 29, 2021), https://www.webmd.com/vaccines/covid-19-vaccine/news/20210129/anti-vaxxersmounting-internet-campaigns-against-covid-19-shots.

${ }^{281}$ Paulsen, supra note 278.
} 
of Cuyahoga River fires, ${ }^{282}$ and the Santa Barbara oil spill from an oil drilling platform. ${ }^{283}$ Before that, the U.S. Army Corps of Engineers had been relying on the Refuse Act ${ }^{284}$ (Section 13 of the Rivers and Harbors Act of 1899) to punish people who polluted the navigable waters, but the statute was an imprecise fit given its larger focus on preserving navigation. ${ }^{285}$ In contrast, Congress had been addressing water quality since 1948 through the Federal Water Pollution Control Act, but until 1972 those efforts focused on encouraging states to address water quality, eventually through setting water quality standards, providing federal money for sewage treatment works, and providing federal research, limiting the federal regulatory role to interstate waters and, in 1970, oil spills. ${ }^{286}$ In 1970 , however, President Richard M. Nixon ordered the brand new Environmental Protection Agency (EPA) and the Army Corps to establish a permit program under the Refuse Act, which the two agencies did within the year. ${ }^{287}$

In 1972, Congress enacted the contemporary version of the Federal Water Pollution Control Act, better known as the Clean Water Act, "to restore and maintain the chemical, physical, and biological integrity of the Nation's waters." 288 The Act was ambitious, and the EPA and the U.S. Army Corps of Engineers, the two federal agencies that implement the Act, as well as states and communities throughout the Nation, failed to achieve the Act's many goals on Congress's original timeline-universal secondary treatment at publicly owned treatment works (POTWs or sewage treatment plants by $1977,{ }^{289}$ fishable and swimmable waters by $1983,{ }^{290}$ and the elimination of all discharges of pollutants by $1985 .{ }^{291}$

Nevertheless, Congress's focus in 1972, and what it eventually did with the Refuse Act permit program, are important background to the current operations of the regulatory shifting baseline syndrome. One of the core regulatory innovations of the 1972 Act was to tie previously existing state water quality standards to federal water quality permitting requirements, in part because of growing

${ }^{282}$ Lorraine Boissoneault, The Cuyahoga River Caught Fire at Least a Dozen Times, but No One Cared Until 1969, SMithSONIAN MAGAzINE, June 19, 2019, https:/www.smithsonianmag.com/history/cuyahoga-river-caught-fire-least-dozen-times-no-onecared-until-1969-180972444/.

${ }^{283}$ Christine Mai-Duc, The 1969 Santa Barbara oil spill changed oil and gas exploration forever, L.A. TIMES (May 20, 2015, 6:38 PM PT), https://www.latimes.com/local/lanow/la-me-ln-santabarbara-oil-spill-1969-20150520-htmlstory.html.

28433 U.S.C. $\$ 407$. For a complete history of the 1972 amendments to the Federal Water Pollution Control Act, see Robin Kundis CRAig, The CleAn WATER ACT AND the Constitution 10-27 (2d ed. ELI 2009); see also Sam Kalen, Commerce to Conservation: The Call for a National Water Policy and the Evolution of Federal Jurisdiction Over Wetlands, 69 N.D. L. REV. 873, 877-79 (1993) (tracing much of this history).

285 CRAIG, supra note 284, at 12 (citations omitted).

${ }^{286} \mathrm{Id}$. at 12-21 (citations omitted).

${ }^{287}$ Id. at 21 (citations omitted).

${ }^{288}$ Pub. L. No. 92-500, § 2, 86 Stat. 818 (Oct. 18, 1972), codified as 33 U.S.C. $\S 1251$ (a).

28933 U.S.C. $\S 1311(\mathrm{~b})(1)(\mathrm{A})$.

${ }^{290}$ Id. $\S 1251(\mathrm{a})(2)$.

${ }^{291}$ Id. $\S 1251(\mathrm{a})(1)$. 
congressional concerns about the impact of water pollution - itself an abuse of the public commons - on public health. ${ }^{292}$

This Part argues that the "waters of the United States" controversy can be helpfully reframed as an instance of the regulatory shifting baseline syndrome. Specifically, significant progress in addressing the classic "tragedy of the commons" water pollution problem has allowed property interests to focus courts' and regulators' attention on other statutory provisions that allow the Act to interfere with private property use and states' primacy in land use planning. In this case, therefore, identifying the regulatory shifting baseline syndrome in action illuminates an important statutory design weakness - one that Congress and the two agencies may simply want to eliminate rather than pursuing yet more rounds of definitional debate over "waters of the United States."

\section{A. U.S. Waterways: From Open Access Resource to Regulated Commons}

Throughout the first two-thirds of the 20th century, rivers in the United States were as often sources of problems as they were amenities. These classic commons resources were widely viewed as free waste disposal facilities, and Hardin's tragedy was often not long in manifesting itself as riverfront cities industrialized. Damage to the larger public good was perhaps most obvious when rivers flowing through and around these cities repeatedly caught fire. Most famously, the Cuyahoga River, which flows through Cleveland, Ohio, caught fire in 1868, 1883, 1887, 1912, 1922, 1936, 1941, 1948, 1952, and 1969; the last first, although not the worst of the series, provided one direct impetus to Congress to intervene in water pollution regulation. ${ }^{293}$ Until the late $1950 \mathrm{~s}$, moreover, residents often viewed the Cuyahoga's and other river's pollution as a sign of progress, even though the growing water pollution problem could also affect their drinking water:

The water was nearly always covered in oil slicks, and it bubbled like a deadly stew. Sometimes rats floated by, their corpses so bloated they were practically the size of dogs. It was disturbing, but it was also just one of the realities of the city. For more than a century, the Cuyahoga River had been prime real estate for various manufacturing companies. Everyone knew it was polluted, but pollution meant industry was thriving, the economy was booming, and everyone had jobs. ${ }^{294}$

\footnotetext{
${ }^{292}$ E.g., S. REP. No.92-214 1972 U.S.C.C.A.N. 3668, 3671 (Oct. 28, 1971).

${ }^{293}$ Boissoneault, supra note 282.

${ }^{294}$ Id. The Clean Water Act does not directly protect drinking water in municipal systems; instead, the Safe Drinking Water Act performs that function. The attribution of almost all drinking water improvements, and hence associated public health benefits, to this later Act has generally skewed cost-benefit analyses of the Clean Water Act. David A. Keiser, Catherine L. King, \& Joseph S. Shapiro, The low but uncertain measured benefits of US water quality policy, 116 PROC. NAT'L ACAD. SCIS. (PNAS) 5262, 5267 (2019). However, more recent and comprehensive studies better
} 
Nor was Cleveland alone in dealing with flammable rivers; "Baltimore, Philadelphia, San Francisco, Buffalo and Galveston all used different methods to disperse oil on their waters in order to prevent fires." 295

Slightly less visibly, rivers also functioned as the United States' primary sewer system. This issue reached the U.S. Supreme Court several times in the first half of the 20th century, particularly when the City of Chicago decided to redirect its raw sewage away from Lake Michigan (the source of its drinking water) through an artificial canal system and into the Mississippi River. Downstream Missouri sued Illinois over the change, first establishing that the Supreme Court had original jurisdiction over interstate pollution cases ${ }^{296}$ and then seeking to shut down the diversion as an interstate nuisance. ${ }^{297}$ Missouri alleged that "the result of the threatened discharge would be to send 1,500 tons of poisonous filth daily into the Mississippi, to deposit great quantities of the same upon the part of the bed of the last named river belonging to the plaintiff, and so to poison the water of that river, upon which various of the plaintiff's cities, towns, and inhabitants depended, as to make it unfit for drinking, agricultural, or manufacturing purposes, ${ }^{298}$ particularly because of an increased risk for typhoid fever. ${ }^{299}$ While there are many notable facets of the Supreme Court's decision that Missouri could not meet its burden of proof for nuisance, most important for this discussion was the fact that essentially every city upstream of St Louis — not to mention St. Louis itself — was discharging its raw sewage into the Mississippi River, making it next to impossible to hold Chicago and Illinois responsible for any health impacts (which were themselves difficult to discern). ${ }^{300}$

In response to a growing environmental consciousness generally, the Cuyahoga River fire of 1969, the Santa Barbara oil spill of 1969, and other impetuses, in 1972 Congress overhauled the Federal Water Pollution Control Act to create the fundamental structure of what is now known as the Clean Water Act. ${ }^{301}$ One of the

account for the pervasive benefits of sewage treatment, which was, at least at the federal level, the sole domain of the Clean Water Act. See generally David A. Keiser \& Joseph S. Shapiro, Consequences of the Clean Water Act and the Demand for Water Quality, 134 QUARTERLY J. ECON. 349 (2019), https://doi.org/10.1093/qje/qiy019 (focusing specifically on the impacts of the Act's sewage treatment grants.

295 Boissoneault, supra note 282.

${ }^{296}$ Missouri v. Illinois, 180 U.S. 208, 248-29 (1901).

${ }^{297}$ Missouri v. Illinois, 200 U.S. 496, 517 (1906).

${ }^{298} \mathrm{Id}$.

${ }^{299} I d$. at $522-23$.

${ }^{300} I d$. at 525-26. See also New Jersey v. New York, 256 U.S. 296, 313-14 (1921) (holding that New Jersey had not (yet) proven that New York's discharges of raw sewage into the Passaic River were a nuisance). Importantly, however, the Court did protect the first municipal sewage treatment plants from being enjoined as nuisances themselves, even though their treatment of the raw sewage was substantially incomplete in many cases. City of Harrisonville, Mo. v. W. S. Dickey Clay Mfg. Co., 289 U.S. 334, 337-40 (1933).

30133 U.S.C. $\S \S 1251-1388$. The name "Clean Water Act" comes from the 1977 amendments. Pub. L. No. 95-217, § 1, 91 Stat. 1567 (Dec. 27, 1977). 
important but less celebrated features of the statute, for example, was its grant program to promote the building and upgrading of sewage treatment plants across the country. ${ }^{302}$ The Act also limited industrial discharges of pollutants into the nation's waterways through two permit programs. ${ }^{303}$

The Clean Water Act has worked, particularly in terms of addressing the commons water pollution problems that induced its drafting. In 2019, David Keiser and Joseph Shapiro published two of the most comprehensive analyses of the Clean Water Act ever done. Noting that, since 1970, the federal government has spent over $\$ 400$ per year for every American "to clean up surface water pollution and provide clean drinking water," 304 they concluded that "many measures of drinking and surface water pollution have fallen since the founding of the Environmental Protection Agency, due at least in part to the Clean Water Act and the Safe Drinking Water Act," although progress remains incomplete. ${ }^{305}$ Specifically, after analyzing 14.6 million pollution measurements taken at 265,000 monitoring sites between 1972 and 2014, Keiser \& Shapiro concluded that "[w]hen the Clean Water Act passed in 1972, nearly 30 percent of water quality readings were unsafe for fishing," while "by 2014 , only about 15 percent were unsafe." ${ }^{306}$ Grants to upgrade sewage treatment plants and enforcement of the Act's National Pollutant Discharge Elimination System (NPDES) permit requirements (see below) were particularly important in reducing water pollution. ${ }^{307}$ More anecdotal evidence also indicates that the Clean Water Act is still working to make progress in this main mission: In March 2019, Cuyahoga River fish were deemed safe to eat, and the river hasn't caught fire since 1972 — although a fuel spill did burn there in August 2020. ${ }^{308}$

\footnotetext{
302 Pub. L. No. 92-500, 86 Stat. 816 (Oct. 18, 1972), codified as amended as 33 U.S.C. §§ 12511388.

30333 U.S.C. $\S \S 1342,1344$; see discussion infra subpart IV.B.

${ }^{304}$ David A. Keiser \& Joseph S. Shapiro, US Water Pollution Regulation over the Past Half Century: Burning Waters to Crystal Springs?, 33 J. ECON. PersPeCtives 51, 52 (2019). The Clean Water Act accounts for about $\$ 100$ per year of that total. Keiser \& Shapiro, Consequences, supra note 294, at 349 .

${ }^{305}$ Keiser \& Shapiro Pollution Regulation, supra note 304, at 53.

306 Id. at 60.

${ }^{307}$ Id. See also Keiser \& Shapiro, Consequences, supra note 294, at 352 ("We find that each grant decreases the probability that downriver areas violate standards for being fishable by half a percentage point. These changes are concentrated within 25 miles downstream of the treatment plant and they persist for 30 years."), 373 ("We find large declines in most pollutants that the Clean Water Act targeted. Dissolved oxygen deficits and the share of waters that are not fishable both decreased almost every year between 1962 and 1990."), 374 ("The share of waters that are not fishable fell on average by about half a percentage point per year, and the share that are not swimmable fell at a similar rate."). Notably, because federal sewage treatment grants began before the 1972 amendments, there were often more declines in sewage pollution before 1972 than after it. $I d$. at 374.

${ }^{308}$ Boissoneault, supra note 282.
} 


\section{B. Structuring the Clean Water Act's Permit Programs}

Water quality regulation in the United States has always been complicated by the fact that certain water polluting activities, traditionally the states' prerogative, can also interfere with navigation, most emphatically the federal government's domain. Thus, by the time Congress overhauled the Federal Water Pollution Control Act in 1972, the Army Corps for decades had been regulating dredging and filling of the navigable waters pursuant to Section 10 of the Rivers and Harbors Act of $1899^{309}$ as a navigation issue. Rivers that can catch on fire are also navigation issues, and, as noted, when Congress overhauled the Federal Water Pollution Control Act in 1972, the EPA and Army Corps had been operating a Refuse Act permit program for pollution for almost two years. ${ }^{310}$

Already, however, Congress was unimpressed. Senate Bill 2770 provided the initial text of the 1972 amendments. As the Senate Committee on Public Works noted in October 1971 in its initial report on that bill,

While the permit program created in late 1970 under the Refuse Act by the Administrator seeks to establish this direct approach, it is weak in two important respects: It is being applied only to industrial polluters, and authority is divided between two Federal agencies.

Experience with the permit system during the past 10 months suggests that the machinery used to date may be as cumbersome as the 1948 abatement procedure. Estimates of the number of permit applications to be received run as high as 300,000; estimates of the time required to process the applications run as long as four years. ${ }^{311}$

The Senate Committee proposed a single permit program, run by the EPA until each state could take it over, with permits containing enforceable effluent limitations. ${ }^{312}$ Water quality standards would now serve as the metrics of progress toward achieving water quality goals. ${ }^{313}$ The Senate bill would have converted Refuse Act permits to NPDES permits, ${ }^{314}$ and the new NPDES permit requirement would also apply to the "at least 40,000" industrial dischargers that the EPA had identified. ${ }^{315}$ However, unlike under the Refuse Act, states would take over the NPDES permit program as they developed the capacity to do so, with federal oversight of their implementation. ${ }^{316}$ Most important for this Article, under the

30933 U.S.C. $\S 403$.

${ }^{310}$ CRAIG, supra note 284 , at 21-22.

${ }^{311}$ S. REP. NO.92-214 1972 U.S.C.C.A.N. 3668, 3672 (Oct. 28, 1971).

${ }^{312} I d$. at 3675-76.

${ }^{313} \mathrm{Id}$. at $3675-76$.

${ }^{314} \mathrm{Id}$. at 3735 .

${ }^{315} \mathrm{Id}$. at 3736 .

${ }^{316} I d$, at $3737-38$. 
Senate's original vision, the NPDES permit program would also largely displace Army Corps "dredge and fill" permits under Section 10 of the Rivers and Harbors Act. $^{317}$

Drafting wrangling with the House of Representatives, however, led to a different final compromise. Under Section 402 of the new Act, Refuse Act permits would still become NPDES permits, and the EPA could eventually delegate NPDES permitting authority to the states-albeit with several new state requirements and expanded EPA oversight, including veto authority. ${ }^{318}$ The House, however, had inserted a new Section 404 permit program, "for the discharge of dredged or fill material into the navigable waters." "319 The conference amendment added new roles for the EPA in this permit program, including giving the EPA "authority to prohibit specification of a site and use of any site for the disposal of any dredge or fill material which he determines will adversely affect municipal water supplies, shellfish beds and fishery areas (including spawning and breeding areas), wildlife, or recreational areas." ${ }^{320}$ As under the Rivers and Harbors Act, however, the focus of the Section 404 permit program remained (at least in Congress's view) preserving navigation, and the Conference Committee "expected that ... unreasonable restrictions shall not be imposed on dredging activities essential to the maintenance of interstate and foreign commerce." 321

As a result, the Clean Water Act emerged from Congress with two permit programs, which have remained in force for almost 50 years. However, the same regulatory prohibition triggers both: except in compliance with the Clean Water Act' requirements, "the discharge of any pollutant by any person shall be unlawful." 322 The Act defines "the discharge of a pollutant" to be "any addition of any pollutant to navigable waters from a point source," 323 where "navigable waters" are "waters of the United States, including the territorial seas." 324 The Act defines "territorial seas" to be the first three miles of ocean, ${ }^{325}$ but it leaves "the waters of the United States" undefined. Interpreting "waters of the United States" "has led to legal debates over how this term applies to roughly half of US waters, primarily composed of wetlands, headwaters, and intermittent streams." 326 This interpretive tension vibrates across the two permit programs, with an emphasis on traditional "navigable waters" making more sense for the Army Corps under section 404, but a broader interpretation of "waters of the United States" better serving the EPA's and Congress's broader water quality goals in the NPDES program.

\footnotetext{
${ }^{317}$ Id. at 3751-52.

318 S. Conf. ReP. No. 92-1236, 1972 U.S.C.C.A.N. 3776, 3816-18 (Sept. 28, 1972).

${ }^{319}$ Id. at $3818-19$.

$320 \mathrm{Id}$. at 3820 .

321 Id. at 3819.

32233 U.S.C. $\$ 1311(\mathrm{a})$.

${ }^{323}$ Id. $\S 1362(12)$.

${ }^{324}$ Id. $\S 1362(7)$.

${ }^{325}$ Id. $\S 1362(8)$.

${ }^{326}$ Keiser \& Shapiro, Pollution Regulation, supra note 304, at 57-58.
} 
The distinction between the two permit programs lies in exactly what pollutant the polluter is discharging. If it is dredged or fill material, the polluter is subject to the Section 404 permit program, which the Army Corps takes lead in implementing. ${ }^{327}$ All other dischargers get NPDES permits. ${ }^{328}$

As the next subpart discusses, the focus of attention between these two permit programs has shifted over time, and, notably, the two U.S. Supreme Court decisions problematizing the scope of "waters of the United States" have come in the context of Section 404 and were decided since 2000, well into the second half of the Act's existence. The shift in focus from NPDEs permits to Section 404 permits, not coincidentally, has allowed the regulatory shifting baseline syndrome to come into play.

\section{From NPDES to Section 404: The Consequences of Shifting Regulatory Attention}

\section{Overview of the U.S. Supreme Court's Clean Water Act Decisions}

Congress's decision to use the same legal test to trigger both permit programs is the Clean Water Act's amnesia-inducing structural feature, because the two regulatory regimes otherwise resonate in very different webs of rights and values. As with the Voting Rights Act's preclearance requirements, the shifting baseline syndrome is most obvious in Supreme Court opinions. Specifically, when evaluating "waters of the United States" from inside the Section 404 web, the Court forgets that what it says that permitting context will simultaneously affect how the NPDES permit program can operate.

As the Senate Committee originally noted, the primary focus of the 1972 amendments was effectively regulating the 40,000 (at least) industrial dischargers that the EPA had discovered-the NPDES permit program-rather than on the Army Corps' continued oversight of the dredging and filling necessary to preserve navigation. And, indeed, the EPA and the courts spent a considerable amount of energy in the first half of the Clean Water Act's existence, from roughly 1972 to 1997, getting the NPDES permit program up and running.

Nevertheless, the historical progression of U.S. Supreme Court's limited pool of decisions about the Clean Water Act suggests a significant shift in regulatory focus over time. As Table 1 indicates, ten of the Court's 17 decisions focused on the Act's NPDES permit program (almost 60\%) occurred in the first half of the Act's existence. In contrast, of the Court's six decisions focused on Section 404, five (more than 83\%) have occurred since 1997. The number increases to six out of seven decisions (almost 86\%) if one considers Coeur Alaska, Inc. v. Southeast Alaska Conservation Council ${ }^{329}$ (2009) to be primarily a Section 404 decision.

32733 U.S.C. $\S 1344(a)$.

${ }^{328}$ Id. $\S 1342(\mathrm{a})$.

329557 U.S. 261 (2009). 
Table 1: The 40 U.S. Supreme Court Decisions about the Clean Water Act

\begin{tabular}{|c|c|c|c|c|}
\hline YEARS & $\begin{array}{c}\text { NPDES } \\
\text { Decisions }\end{array}$ & $\begin{array}{c}\text { Section } 404 \\
\text { Decisions }\end{array}$ & $\begin{array}{c}\text { Decisions } \\
\text { Involving } \\
\text { Both } \\
\text { Permit } \\
\text { Programs } \\
\end{array}$ & $\begin{array}{c}\text { Decisions not } \\
\text { Involving Permit } \\
\text { Programs }\end{array}$ \\
\hline $1972-1976$ & 2 & NONE & NONE & $\begin{array}{l}\text { - Sewage treatment } \\
\text { funds: } 2 \\
\text { - Radioactive } \\
\text { materia1s: } 1 \\
\text { - Interstate nuisance: } \\
1\end{array}$ \\
\hline $1977-1981$ & 4 & NONE & NONE & $\begin{array}{l}\text { - Federal common } \\
\text { law preempted: } 2 \\
\text { - Civil penalties } \\
\text { don't trigger } \\
\text { criminal law } \\
\text { protections: } 1\end{array}$ \\
\hline 1982-1986 & 2 & $\begin{array}{c}\text { 1: } \\
\text { Riverside } \\
\text { Bayview }\end{array}$ & NONE & NONE \\
\hline 1987-1991 & 1 & NONE & NONE & $\begin{array}{l}\text { - State nuisance } \\
\text { law: } 1 \\
\text { - Jury trial: } 1 \\
\text { - Forest Service } \\
\text { plans: } 1 \\
\end{array}$ \\
\hline 1992-1996 & 1 & & & $\begin{array}{l}\text { - Federal facility } \\
\text { liability: } 1 \\
\text { - Section } 401 \\
\text { certification: } 1 \\
\text { - Attorney fees: } 1 \\
\end{array}$ \\
\hline $1997-2001$ & 1 & $\begin{array}{c}\text { 1: } \\
\text { SWANCC }\end{array}$ & NONE & NONE \\
\hline $2002-2006$ & 1 & $\begin{array}{c}\text { 2: } \\
\text { Borden Ranch } \\
\text { \& Rapanos } \\
\end{array}$ & NONE & - Section 401: 1 \\
\hline $2007-2011$ & 2 & & $\begin{array}{c}\text { 1: } \\
\text { Coeur Alaska }\end{array}$ & $\begin{array}{l}\text { - Preemption of } \\
\text { maritime law: } 1 \\
\end{array}$ \\
\hline $2012-2016$ & $\begin{array}{c}\mathbf{2}: \\
\text { Decker \& Los } \\
\text { Angeles County }\end{array}$ & $\begin{array}{c}\text { 2: } \\
\text { Sackett \& } \\
\text { Hawkes }\end{array}$ & NONE & NONE \\
\hline $2017-2020$ & $\begin{array}{c}\text { 1: } \\
\text { County of Maui }\end{array}$ & NONE & $\begin{array}{c}1: \\
\text { Where to } \\
\text { challenge } \\
\text { WOTUS regs }\end{array}$ & NONE \\
\hline TOTALS & 17 & 6 & 2 & 15 \\
\hline
\end{tabular}


In addition to shifting focus to the Section 404 context, the Court's decisions regarding the two permit programs are often qualitatively different in how they approach the Clean Water Act. Some of these differences are evident in the permit programs themselves. For example, in Coeur Alaska, the Court had to decide which permit program applied to Coeur Alaska's discharge of a mine tailings slurry from its Kensington Gold Mine into Slate Lake. ${ }^{330}$ "Over the life of the mine, Coeur Alaska intend[ed] to put 4.5 million tons of tailings in the lake" 331 at a rate of 210,000 gallons per day, effectively destroying the lake for the duration of the mine and "kill[ing] all of the lake's fish and nearly all of its other aquatic life." 332 This result was perfectly legal under the Section 404 permit program, so long as Coeur Alaska restored the lake at the end of the process and kept it isolated from other waters in the interim - and, the Army Corps concluded, using Slate Lake this way was better for the environment than disposing of the tailings in nearby wetlands. ${ }^{333}$ Under the NPDES program, in contrast, the discharge was completely illegal under the EPA's effluent limitations for the froth-floatation gold mining industry. ${ }^{334}$ The Court's six-Justice majority accorded Chevron deference to the Army Corps' and EPA's decision that the Section 404 program applied because Coeur Alaska was "filling" Slate Lake. ${ }^{335}$ Among other things, this decision makes clear that the Army Corps' founding instruction to promote commercial activity continues to conflict with the EPA's ca to protect the nation's waters.

\section{The Supreme Court's View of the NPDES Permit Program: Protect the Public Commons}

NPDES permits address classic water pollution by imposing "end of the pipe" limitations (the effluent limitations) on how much or what concentration of pollutants the polluter can discharge into the waterway, ${ }^{336}$ generally based on the control technologies available to the polluter's industrial category. As such, NPDES permits condition how businesses can operate but, usually, not whether they can exist. Moreover, the public benefits of the program are almost always easy to explain. Navigable waterbodies have long been deemed a public resource that should support navigation and fishing, and even privately owned smaller streams flow into larger waters, making the externalities and public harms of traditional

\footnotetext{
330557 U.S. 261, 267 (2009).

${ }^{331} \mathrm{Id}$. at 268.

332 Id. at 297 (Ginsburg, J., dissenting).

${ }^{333} I d$. at 269-70. Forbidding the mine from damaging either water of the United States apparently never occurred to the Army Corps.

${ }^{334} \mathrm{Id}$. at $278-79$ (citing 33 U.S.C. $\S 1316(\mathrm{~b}), 40$ C.F.R. $\S 440.104(\mathrm{~b})(1)$ ).

${ }^{335} I d$. at 275, 277, 290-91. Along the way, the Court also deferred to the agencies' conclusion that the permit programs are mutually exclusive: any specific discharge is subject to one or the other, but not both. $I d$. at 274-75.

33633 U.S.C. $§ 1362(11)$
} 
water pollution fairly obvious even for these smaller waters. NPDES regulation thus resonates strongly with common-law nuisance constraints on private action. ${ }^{337}$

In this regulatory context, the Supreme Court has long read the Act broadly to effectuate Congress's goal of reducing water pollution and to strengthen the EPA's authority to make progress toward that goal. For example, one of the Court's earliest NPDES decisions, E.I. du Pont de Nemours \& Co. v, Train (1977), emphasized that " $[\mathrm{t}]$ he statute, enacted on October 18, 1972, authorized a series of steps to be taken to achieve the goal of eliminating all discharges of pollutants into the Nation's waters by 1985 ...."338 The issue was whether the EPA had authority under the Act to issue industry-wide effluent limitations by regulation, as opposed to setting facility-specific effluent limitations in the process of writing each discharger's permit. ${ }^{339}$ In upholding the EPA's authority based on both the statutory language and the legislative history, ${ }^{340}$ the Court also elaborated upon the impediment that du Pont's approach would pose to improving water quality:

The petitioners' view of the Act would place an impossible burden on EPA. It would require EPA to give individual consideration to the circumstances of each of the more than 42,000 dischargers who have applied for permits, ... and to issue or approve all these permits well in advance of the 1977 deadline in order to give industry time to install the necessary pollution-control equipment. We do not believe that Congress would have failed so conspicuously to provide EPA with the authority needed to achieve the statutory goals. ${ }^{341}$

Similarly, in EPA v. National Crushed Stone Association (1980), the Court upheld the EPA's decision not to allow variances from the first phase of effluent limitations just because the discharger could not afford the "best practicable technology." 342 "Necessarily, if pollution is to be diminished, limitations based on BPT must forbid the level of effluent produced by the most pollution-prone segment of the industry, that segment not measuring up to 'the average of the best existing performance.' So understood, the statute contemplated regulations that would require a substantial

\footnotetext{
${ }^{337}$ Indeed, "In 1998, a Washington State court found that even lawful operation of a business - a pulp mill operating with a Federal Water Pollution Control Act national pollution discharge elimination system (NPDES) permit allowing it to discharge treated process wastewater into the Columbia River - could support an award of \$2.5 million in damages for nuisance to potato farmers drawing irrigation water from the aquifer contaminated by the defendant's operation." Denise Antolini \& Clifford L. Rechtschaffen, Common Law Remedies: A Refresher, 38 ENVTL. L. REP. NEWS \& ANALYsis 10114, 10119 (2008) (citing Tiegs v. Watts, 954 P.2d 877, 883 (Wash. 1998)).

338430 U.S. 112, 116 (1977).

${ }^{339} I d$. at $125-26$.

${ }^{340} \mathrm{Id}$. at $129-32$.

${ }^{341} \mathrm{Id}$. at 132-33.

342449 U.S. 64, 83-84 (1980).
} 
number of point sources with the poorest performances either to conform to BPT standards or to cease production." 343

This trend continues into the Court's most recent NPDES decision, County of Maui v. Hawaii Wildlife Fund (2020), where the Court once again emphasized the Act's purpose to clean up the nation's waterways. ${ }^{344}$ At issue was a sewage treatment plant located north of Lahaina on the island of Maui, Hawai'i, and the Court majority stressed the water quality problem that it was causing: "The facility collects sewage from the surrounding area, partially treats it, and pumps the treated water through four wells hundreds of feet underground. This effluent, amounting to about 4 million gallons each day, then travels a further half mile or so, through groundwater, to the ocean." 345 The issue was whether this conveyance through groundwater constituted a discharge "from a point source" into the Pacific Ocean that triggered the Act. ${ }^{346}$ The Court sought to find a middle ground between a broad reading that would essentially require a permit regardless of how convoluted the links between the discharger and the receiving "water of the United States" actually were $^{347}$ and a narrow reading that would create a "large and obvious loophole" in the NPDES program any time pollutants passed through groundwater on their way to a surface water body. ${ }^{348}$ As a result, the Court concluded that the facility could be subject to the NPDES permit program if the injection was the "functional equivalent of a direct discharge." 349

To be sure, some of the Court's recent decisions also constrain the NPDES program's reach. However, these decisions tend to turn on complications other than the Court's own construction of the Act. For example, in Los Angeles County Flood Control District v. Natural Resources Defense Council (2013), the problem was a badly framed issue on certiorari that turned a complex issue about Los Angeles County's ultimate responsibility for meeting water quality standards into an overly simplistic issue of whether a discharge occurs when water flows from a channelized portion of the Los Angeles River into a more natural portion; ${ }^{350}$ prior caselaw made it clear that the answer was "no." 351 Decker v. Northwest Environmental Defense Center (2013), in turn, turned on the Court giving Auer deference to the EPA's counterintuitive interpretation of its own regulation to conclude that logging roads are not subject to the NPDES program's stormwater requirements, ${ }^{352}$ an issue that

\footnotetext{
${ }^{343} I d$. at 76.

344 --- U.S. ---, 140 S. Ct. 1462, 1468, (2020) (quoting 33 U.S.C. $§ 1251(a)$ ).

${ }^{345} \mathrm{Id}$. at 1469.

346 Id. at 1470 .

${ }^{347} \mathrm{Id}$. at $1470-73$.

${ }^{348} I d$. at 1473 (citations omitted).

${ }^{349} \mathrm{Id}$. at 1476.

350568 U.S. 78, 80 (2013).

${ }^{351} \mathrm{Id}$. at 82-84. Notably, the Court's decision was only six pages long.

352568 U.S. 597, 612-14 (2013).
} 
put the NPDES program's goal and the EPA's authority to administer that program squarely in conflict. ${ }^{353}$

\section{The Supreme Court's View of "Waters of the United States" through the Section 404 Permit Program: Protect State Prerogatives and Private Property Rights}

The Section 404 permit program has moved far beyond Congress's 1972 vision of dredging and filling to maintain navigation. Consistent with Congress's view that Section 404 permits were mostly about navigation, the Army Corps' regulations originally restricted "waters of the United States" to the traditionally navigable waters. ${ }^{354}$ However, because the EPA eventually forced the Army Corps to define "waters of the United States" to the limits of the Commerce Clause, 355 Section 404 now requires permits for the dredging and filling of some subset of smaller waters, including wetlands and small and intermittent streams. People who now qualify for the Section 404 permit program are often ditching and/or filling the soggier parts of their property before building something. Unlike NPDES permits, therefore, Section 404 permits can and often do directly interfere with the development of private property, particularly larger development projects. ${ }^{356}$ It is no accident, in other words, that almost all constitutional takings litigation that the Clean Water Act has generated comes out of the Section 404 permitting program. ${ }^{357}$ Moreover, wrangling over what uses can and cannot occur on private property means that the Army Corps makes decisions in Section 404 permits that can look a lot like land use planning, a traditional area of state authority. ${ }^{358}$

\footnotetext{
${ }^{353}$ See also Entergy Corp. v. Riverkeeper, Inc., 556 U.S. 208. 217-27 (2009) (according Chevron deference to the EPA's decision to use cost-benefit analysis to determine the level of technological stringency required for power plant cooling water intake structures, even though the standards chosen were not the most protective of aquatic life).

${ }^{354}$ United States v. Riverside Bayview Homes, Inc., 474 U.S. 121, 123 (1985).

${ }^{355}$ See id. at 123-24 (recounting this history and citing 40 Fed. Reg. 31,320 1975).

${ }^{356}$ E.g.. Forest Properties, Inc. v. United States, 177 F.3d 1360, 1363 (Fed. Cir. 1999) (noting that the denial of the Section 404 permit ended development of cabins on a lakebed); Florida Rock Industries v. United States. 21 Cl. Ct. 161, 164 (1990) (noting that a denial of a Section 404 permit prevented a limestone mine from operating).

${ }^{357}$ E.g., Riverside Bayview Homes, 474 U.S. at 126-29 (discounting the seriousness of the taking issue as "spurious constitutional overtones"); Cooley v. United States, 324 F.3d 1297, 1300 (Fed. Cir. 2002) (asserting a takings claim based on the Army Corps' denial of a Section 404 permit); Forest Properties, Inc. 177 F.3d at 1364 (asserting a regulatory takings claim on the basis of a Section 404 permit denial); City National Bank of Miami v, United States, 33 Fed. Cl. 759 (1995) (takings claim occasioned by denial of Section 404 permit). A corresponding Westlaw search for takings claims in connection with the NPDEs program revealed no reported decisions.

${ }^{358}$ E.g., Riverside Bayview Homes, 474 U.S. at 126 (virtually equating Section 404 permits with land use planning); Rapanos v. United States, 547 U.S. 715, 738 (2006) ("Regulation of land use, as through the issuance of the development permits sought by petitioners in both of these cases, is a quintessential state and local power." (citing FERC v. Mississippi, 456 U.S. 742, 767-768, n. 30 (1982); Hess v. Port Authority Trans-Hudson Corporation, 513 U.S. 30, 44 (1994))).
} 
Thus, litigation over the Section 404 permit program has shifted the Court's attention away from improving water quality and safeguarding the EPA's authority to protecting private property rights and states' traditional authorities. In the process, this litigation has also focused on the scope of "waters of the United States," eventually creating a definitional mess that now limits the NPDES program, as well.

Indeed, in the Supreme Court, the controversy over the proper definition of "waters of the United States" has played out entirely in the Section 404 context. The first decision, United States v. Riverside Bayview Homes, Inc. (1985), ${ }^{359}$ felt much like the NPDES decisions: the Court unanimously held that the Army Corps can regulate the dredging and filling of wetlands adjacent to traditionally navigable bodies of water, in order to fulfill the Act's water quality goals. ${ }^{360}$ The defendant, Riverside Bayview Homes, Inc., owned 80 acres of low-lying, marshy land near the shores of Lake St. Clair in Macomb County, Michigan. In 1976, it began to fill these wetlands to build a housing development. Giving Chevron deference to the Army Corps' regulations interpreting "waters of the United States," the Riverside Bayview Court concluded that applying the Clean Water Act to "adjacent wetlands" made sense, because "the evident breadth of congressional concern for protection of water quality and aquatic ecosystems suggests that it is reasonable for the Corps to interpret the term 'waters' to encompass wetlands adjacent to waters as more conventionally defined." 361 Moreover, the Court conceived of "waters of the United States" as significantly broader than the traditional navigable waters:

Congress chose to define the waters covered by the Act broadly. Although the Act prohibits discharges into "navigable waters," ... the Act's definition of "navigable waters" as "the waters of the United States" makes it clear that the term "navigable" as used in the Act is of limited import. In adopting this definition of "navigable waters," Congress evidently intended to repudiate limits that had been placed on federal regulation by earlier water pollution control statutes and to exercise its powers under the Commerce Clause to regulate at least some waters that would not be deemed "navigable" under the classical understanding of that term. ${ }^{362}$

Nevertheless, in a footnote, the Riverside Bayview Court also specified that " $[\mathrm{w}] \mathrm{e}$ are not called upon to address the question of the authority of the Corps to regulate discharges of fill material into wetlands that are not adjacent to bodies of open water ... and we do not express any opinion on that question." 363

\footnotetext{
359474 U.S. 121 (1985).

${ }^{360} \mathrm{Id}$. at $132-33$.

${ }^{361} \mathrm{Id}$. at $130-31$.

${ }^{362} \mathrm{Id}$. at 133 (citations to statute omitted).

${ }^{363}$ Id. at 131-32 n.8. The Court's 2002 decision in Borden Ranch Partnership v. U.S. Army Corps of Engineers also technically upheld Section 404 jurisdiction over "deep ripping" of wetlands at a
} 
In 1986, the Army Corps revised its regulations. In the preamble to those revisions-but not in the regulations themselves - the Corps noted that it would assert Clean Water Act jurisdiction over any intrastate waters:

(i) Which are or would be used as habitat by birds protected by Migratory Bird Treaties; or

(ii) Which are or would be used as habitat by other migratory birds which cross state lines; or

(iii) Which are or would be used as habitat for endangered species; or

(iv) Used to irrigate crops sold in interstate commerce. ${ }^{364}$

These non-regulatory assertions of jurisdiction became known, collectively, as the "Migratory Bird Rule." The Migratory Bird Rule led directly to the Supreme Court's 2001 decision in Solid Waste Agency of Northern Cook County v. U.S. Army Corps of Engineers, ${ }^{365}$ better known as SWANCC. SWANCC involved an abandoned sand and gravel mining site that 23 cities and villages in suburban Chicago wanted to convert to a sanitary landfill. Several of the abandoned gravel pits had filled with water, and, while the Army Corps did not consider them wetlands, over 121 species of birds used the ponds, including migratory birds. ${ }^{366}$ The Army Corps asserted jurisdiction over the site on the basis of the Migratory Bird Rule and denied SWANCC a Section 404 permit to fill the ponds. ${ }^{367}$ When SWANCC appealed, the Supreme Court held, 5-4, that the Army Corps and EPA could not use the Migratory Bird Rule to regulate intrastate, isolated waters. ${ }^{368}$ Along the way, moreover, the majority emphasized that:

We cannot agree that Congress' separate definitional use of the phrase "waters of the United States" constitutes a basis for reading the term "navigable waters" out of the statute. ... The term "navigable" has at least the import of showing us what Congress had in mind as its authority for enacting the CWA: its traditional jurisdiction over waters that were or had been navigable in fact or which could reasonably be so made. ${ }^{369}$

vineyard, but the 4-4 split among the Justices merely affirmed the U.S. Court of Appealsfor the Ninth Circuit as a default, and the entire opinion consists of two sentences: "The judgment is affirmed by an equally divided Court. Justice KENNEDY took no part in the consideration or decision of this case." 537 U.S. 99, 100 (2002).

${ }^{364}$ Final Rule for Regulatory Programs of the Corps of Engineers, 51 Fed. Reg. 41,206, 41,217 (Nov. 13, 1986)

365531 U.S. 159 (2001).

${ }^{366} \mathrm{Id}$. at $164-65$.

${ }^{367} I d$. at 165 .

${ }^{368} \mathrm{Id}$. at 174.

${ }^{369}$ Id. at 171-72 (citing United States v. Appalachian Elec. Power Co., 311 U.S. 377, 407-408 (1940)). 
The SWANCC majority also refused to defer to the Army Corps' regulatory definition of "waters of the United States." 370 It emphasized, for example, that "Congress chose to 'recognize, preserve, and protect the primary responsibilities and rights of States to prevent, reduce, and eliminate pollution, to plan the development and use (including restoration, preservation, and enhancement) of land and water resources ... ." 371 The Army Corps' regulations raised "significant constitutional questions" of federalism, and allowing the agency "to claim federal jurisdiction over ponds and mudflats falling within the 'Migratory Bird Rule' would result in a significant impingement of the States' traditional and primary power over land and water use." 372

Notably, Chief Justice Rehnquist's opinion for the five-Justice majority did not even acknowledge the NPDES program. Perhaps more surprisingly, Justice Stevens' opinion for the dissenters is similarly myopic. It does start with a broad vision of the Act, noting that "[a]lthough Congress' vision of zero pollution remains unfulfilled, its pursuit has unquestionably retarded the destruction of the aquatic environment. Our Nation's waters no longer burn. Today, however, the Court takes an unfortunate step that needlessly weakens our principal safeguard against toxic water." 373 From there, however, the dissenters focus exclusively on Section 404, including its differences from the Rivers and Harbors Act, ${ }^{374}$ why the Army Corps changed its mind about the scope of "waters of the United States," 375 and how Section 404 does indeed respect state authority 376 and does not infringe upon the Commerce Clause's scope. ${ }^{377}$ Caught up in the property and federalism drama of Section 404, the Court apparently simply forgot about the implications of its decision for the NPDES program.

Rapanos v. United States $(2006)^{378}$ fractured the Supreme Court, and there has been no national unity regarding "waters of the United States" ever since. As the plurality of four Justices, in an opinion by Justice Scalia, described the facts, John Rapanos backfilled wetlands to develop a parcel of private property in Michigan that "included 54 acres of land with sometimes-saturated soil conditions," although "[t]he nearest navigable water was 11 to 20 miles away." 379 From there, the plurality opinion is a rant against the Army Corp's intrusion into private property rights and state land use planning, worth reproducing fully:

${ }^{370} \mathrm{Id}$. at 168 (noting that 'the Corps' original interpretation of the CWA, promulgated two years after its enactment, is inconsistent with that which it espouses here"), 172 (explicitly refusing to extend Chevron deference).

${ }^{371} \mathrm{Id}$. at 166-67 (citing 33 U.S.C. $\S 1251(\mathrm{~b})$ ).

${ }^{372} \mathrm{Id}$. at 174 .

${ }^{373} I d$. at 175 (Stevens, J., dissenting).

${ }^{374}$ Id. at 179-182 (Stevens, J., dissenting).

${ }^{375} \mathrm{Id}$. at 183-191 (Stevens, J., dissenting).

${ }^{376}$ Id. at 191-92 (Stevens, J., dissenting).

${ }^{377}$ Id. at 192-97 (Stevens, J., dissenting).

378547 U.S. 715 (2006).

${ }^{379}$ Id . at $719-21$. 
The burden of federal regulation on those who would deposit fill material in locations denominated "waters of the United States" is not trivial. In deciding whether to grant or deny a permit, the U.S. Army Corps of Engineers (Corps) exercises the discretion of an enlightened despot, relying on such factors as "economics," "aesthetics," "recreation," and "in general, the needs and welfare of the people," 33 CFR $\S 320.4$ (a) (2004). The average applicant for an individual permit spends 788 days and $\$ 271,596$ in completing the process, and the average applicant for a nationwide permit spends 313 days and $\$ 28,915$ - not counting costs of mitigation or design changes. ... "[O]ver $\$ 1.7$ billion is spent each year by the private and public sectors obtaining wetlands permits." These costs cannot be avoided, because the Clean Water Act "impose[s] criminal liability," as well as steep civil fines, "on a broad range of ordinary industrial and commercial activities." ... In this litigation, for example, for backfilling his own wet fields, Mr. Rapanos faced 63 months in prison and hundreds of thousands of dollars in criminal and civil fines.

The enforcement proceedings against Mr. Rapanos are a small part of the immense expansion of federal regulation of land use that has occurred under the Clean Water Act - without any change in the governing statute-during the past five Presidential administrations. In the last three decades, the Corps and the Environmental Protection Agency (EPA) have interpreted their jurisdiction over "the waters of the United States" to cover 270-to-300 million acres of swampy lands in the United States - including half of Alaska and an area the size of California in the lower 48 States. And that was just the beginning. The Corps has also asserted jurisdiction over virtually any parcel of land containing a channel or conduitwhether man-made or natural, broad or narrow, permanent or ephemeral - through which rainwater or drainage may occasionally or intermittently flow. On this view, the federally regulated "waters of the United States" include storm drains, roadside ditches, ripples of sand in the desert that may contain water once a year, and lands that are covered by floodwaters once every 100 years. Because they include the land containing storm sewers and desert washes, the statutory "waters of the United States" engulf entire cities and immense arid wastelands. In fact, the entire land area of the United States lies in some drainage basin, and an endless network of visible channels furrows the entire surface, containing water ephemerally 
wherever the rain falls. Any plot of land containing such a channel may potentially be regulated as a "water of the United States." 380

Moreover, "[t]he extensive federal jurisdiction urged by the Government would authorize the Corps to function as a de facto regulator of immense stretches of intrastate land - an authority the agency has shown its willingness to exercise with the scope of discretion that would befit a local zoning board." 381

To correct this unwarranted and possibly unconstitutional expansion of federal power, the plurality focused on the meaning of "waters," concluding that:

"the waters of the United States" include only relatively permanent, standing or flowing bodies of water. The definition refers to water as found in "streams," "oceans," "rivers," "lakes," and "bodies" of water "forming geographical features." All of these terms connote continuously present, fixed bodies of water, as opposed to ordinarily dry channels through which water occasionally or intermittently flows. Even the least substantial of the definition's terms, namely, "streams," connotes a continuous flow of water in a permanent channel-especially when used in company with other terms such as "rivers," "lakes," and "oceans." None of these terms encompasses transitory puddles or ephemeral flows of water. ${ }^{382}$

This time, however, the federal government and various amici put the NPDES problem squarely in front of the Court, arguing that the plurality's interpretation would allow polluters to evade the NPDES permit requirement, as well. ${ }^{383}$ The plurality disagreed, arguing that NPDEs discharges to not have to reach "waters of the United States directly, "that the discharge into intermittent channels of any pollutant that naturally washes downstream likely violates $\S 1311(\mathrm{a})$, even if the pollutants discharged from a point source do not emit 'directly into' covered waters, but pass 'through conveyances' in between," and that the intermittent conveyances might themselves qualify as point sources. ${ }^{384}$ In this respect, the plurality concluded, there were important differences between dredged and fill material and other pollutants:

In contrast to the pollutants normally covered by the [NPDES] permitting requirement of $\S 1342(\mathrm{a})$, "dredged or fill material," which is typically deposited for the sole purpose of staying put, does not normally wash downstream, and thus does not normally

${ }^{380} I d$. at $721-22$ (citations omitted).

${ }^{381} I d$. at 738 .

${ }^{382} \mathrm{Id}$. at $732-33$.

${ }^{383} \mathrm{Id}$. at $742-43$.

${ }^{384}$ Id. at $743-44$. 
constitute an "addition ... to navigable waters" when deposited in upstream isolated wetlands. ... It does not appear, therefore, that the interpretation we adopt today significantly reduces the scope of $\S$ $1342 .^{385}$

One can speculate whether the plurality Justices had ever actually observed dredging and filling operations. ${ }^{386}$ Nevertheless, regardless of how one judges the sincerity of their attempt to distinguish the NPDES program, it is clear that concerns about the NPDES program were not going to alter their decision to constrain Section 404. These Justices' regulatory focus had thus shifted decisively from promoting continued progress in reducing water pollution to reining in Section 404's alleged overreaching.

Neither Justice Kennedy in concurrence nor the dissenters agreed that the plurality had arrived at the correct test for "waters of the United States." Justice Kennedy harkened back to Riverside Bayview to emphasize hydrological connectivity, and under his test "the Corps' jurisdiction over wetlands depends upon the existence of a significant nexus between the wetlands in question and navigable waters in the traditional sense." 387 Moreover, "wetlands possess the requisite nexus, and thus come within the statutory phrase 'navigable waters,' if the wetlands, either alone or in combination with similarly situated lands in the region, significantly affect the chemical, physical, and biological integrity of other covered waters more readily understood as "navigable." "388 The four dissenting Justices, in an opinion by Justice Stevens, would have maintained broad jurisdiction over wetlands and other waters but-recognizing that lower courts now had two other tests to decide between - concluded that a "water of the United States" existed if either the plurality's or Justice Kennedy's test was met. ${ }^{389}$

Since Rapanos, there has been no agreement what to do about the definition of "waters of the United States." Proposed amendments in Congress failed, ${ }^{390}$ and the U.S. Courts of Appeals maintain a circuit split over whether to use the dissenter's "either/or" approach or whether Justice Kennedy's test controls; none use only the plurality test. ${ }^{391}$ Each of the Obama and Trump Administrations promulgated "waters of the United States" regulations that were promptly challenged in multiple courts, ${ }^{392}$ and at one point in 2020, both sets of regulations, as well as the EPA's

\footnotetext{
${ }^{385} \mathrm{Id}$. at $744-45$.

${ }^{386}$ Notably, both Justice Kennedy and the dissenters questioned the factual accuracy of the plurality's assertion that dredged and fill material stays in place. Id. at $774-75$ (Kennedy, J., concurring), 806-07 (Stevens, J., dissenting).

${ }^{387} \mathrm{Id}$. at 779 (Kennedy, J., concurring).

${ }^{388} \mathrm{Id}$. at 780 (Kennedy, J., concurring).

${ }^{389} \mathrm{Id}$. at 810 (Stevens, J., dissenting).

390 Robin Kundis Craig, Environmental Law in CONTEXT: CASES AND MATERials XX (5th ed. forthcoming 2021).

${ }^{391} I d$. at XX.

${ }^{392}$ For a summary of the reactions to the 2015 Obama Administration Clean Water Rule, see Dave Owens, Little Streams and Legal Transformations, 2017 UTAH L. REV. 1, 2-3.
} 
and Army Corps' pre-Rapanos regulations, were being challenged in litigation, with confusion and cross-injunctions escalating to the point where not even the EPA was sure which regulations applied in New Mexico. ${ }^{393}$ It is expected that the Biden Administration will formally withdraw the Trump Administration's regulations and return for a time to the post-Rapanos circuit split before proposing new "waters of the United States" regulations of its own. ${ }^{394}$ Inevitably, regardless of what they say, court challenges will follow.

Nevertheless, the Supreme Court has continued to pursue a pro-property owner agenda in cases involving Section 404. Both Sackett v. Environmental Protection Agency (2012) ${ }^{395}$ and U.S. Army Corps of Engineers v. Hawkes Co. (2016) ${ }^{396}$ involved the right of property owners to immediately challenge the Army Corps' and EPA's determinations that the Clean Water Act applies to wetlands and other waters on their properties. In Sackett, the Sacketts filled in part of their Idaho lot in order to build a house, only to receive an EPA compliance order concluding that they were filling jurisdictional wetlands and requiring them to restore the property. ${ }^{397}$ The Court unanimously concluded that the compliance order was "final agency action" subject to immediate judicial review. ${ }^{398}$ Justice Alito concurred to emphasize that "[t]he position taken in this case by the Federal Government - a position that the Court now squarely rejects - would have put the property rights of ordinary Americans entirely at the mercy of Environmental Protection Agency (EPA) employees." "399

In Hawkes, Hawkes Co. was engaged in mining peat from bogs that the Army Corps concluded were subject to the Clean Water Act, and Hawkes Co. wanted to challenge that determination before actually going through the permitting process. All nine Justices again concurred that an Army Corps jurisdictional determination is "final agency action" 400 subject to judicial review. However, for Chief Justice Roberts - in an opinion eight Justices joined in full — the stakes in the Section 404 context were particularly high and worth laying out in detail, and he quoted at length the plurality opinion in Rapanos regarding the costs and extensive jurisdiction of Section 404 permits. ${ }^{401}$ Together, therefore, Sackett and Hawkes evidence a clear Supreme Court determination to ensure that private property

\footnotetext{
${ }^{393}$ CRAIG, ELIC, supra note 390 at XX; see also Congressional Research Service, Evolution of the Meaning of "Waters of the United States" in the Clean Water Act 23-32. 33 fig. 2 (updated March 5, 2019), available at https://crsreports.congress.gov/product/pdf/R/R44585 (summarizing the litigation and providing a map of which rules applied where as of 2019).

394 E.g., Bobby Magill, Biden Swings Waters Pendulum With Final Resolution Still Elusive, BlOOMBERG LAW (Jan. 29, 2021, 3:30 AM), https://news.bloomberglaw.com/environment-andenergy/biden-swings-waters-pendulum-with-final-resolution-still-elusive.

395566 U.S. 120 (2012).

396 --- U.S. ---, 136 S. Ct. 1807 (2016).

${ }^{397}$ Sackett, 566 U.S. at 123-25.

${ }^{398} I d$. at 131.

${ }^{399} I d$. at 132 (Alito, J., concurring).

${ }^{400}$ Hawkes Co., 136 S. Ct. at 1816, 1817-18 (Ginsburg, J., concurring).

${ }^{401} \mathrm{Id}$. at $1811-12$.
} 
owners can have their day in court before the Clean Water Act can limit how they develop their land.

\section{What Lessons Does the Regulatory Shifting Baseline Syndrome Offer for the Clean Water Act?}

As the Congressional Research Service recognized in 2019, "During the first two decades after the passage of the Clean Water Act, courts generally interpreted the act as having a wide jurisdictional reach." 402 During this 20 -year period, the Supreme Court focused exclusively on the NPDES program, generally upholding the EPA's authority "to restore and maintain the chemical, physical, and biological integrity of the Nation's waters." The EPA and the courts got the NPDES program up and running, and Congress has not changed that program significantly since the 1987 amendments that required permits for municipal and industrial stormwater discharges. ${ }^{403}$

It worked. Rivers no longer burn and, for the most part, cities no longer discharge raw sewage into the nation's waterways. ${ }^{404}$ Water quality nationwide has gotten better. ${ }^{405}$ Supreme Court attention has shifted to Section 404, and it "has emphasized that 'the grant of authority to Congress under the Commerce Clause, though broad, is not unlimited." "406

Regardless of what the Rapanos plurality may have intended, the Rapanos problematization of "waters of the United States" spilled into the NPDES context, absolving multiple polluters of the obligation to get a Clean Water Act permit. ${ }^{407}$ Thus, in shifting the relevant regulatory baseline from NPDES program's control over paradigmatic municipal and industrial dischargers to Section 404's impact on private landowners and state land use planning federalism prerogatives, a majority of Justices are in fact suffering from a form of the regulatory shifting baseline syndrome - a discounting of the danger to continuing progress in improving the

402 Congressional Research Service, Evolution of the Meaning of "Waters of the United States" in the Clean Water Act 1 (updated March 5, 2019), available at https://crsreports.congress.gov/product/pdf/R/R44585.

${ }^{403}$ Pub. L. No. 100-4, $\S \S 401-405,101$ Stat. 65-69 (Feb. 4, 1987).

${ }^{404}$ As of 2017, an estimated 14,748 POTWs served approximately $81 \%$ of U.S. households; most of the rest relied on septic tanks. U.S. Wastewater Treatment Fact Sheet, CTR. SuSTAINABLE SySTEMS, UNIV. MiCHIGAN (2017), http://css.umich.edu/factsheets/us-wastewater-treatmentfactsheet. However, wet weather events can still cause problems for sewage systems. Sanitary Sewer Overflows, U.S. Envtl. Protection Agency (updated Aug. 14, 2020), https://www.epa.gov/npdes/sanitary-sewer-overflows-ssos.

${ }^{405}$ See generally Keiser \& Shapiro, Consequences, supra note 294

${ }^{406}$ Congressional Research Service, supra note 402, at 1.

407 E.g., Black Warrior River-Keeper, Inc. v. Drummond Co., Inc., 387 F. Supp. 1271, 1289 (N.D. Ala. 2019); Environmental Protection Information Center v. Pacific Lumber Co., 469 F. Supp. 2d 803, 822 (N.D. Cal. 2007); In re: Arizona Public Service Co., 2020 WL 6255456, at*17-*18 (EPA EAB Sept. 30, 2020). 
nation's water quality resulting from the fact that Section 404 raises completely different issues.

Here, however, there is no single restorative solution. Instead, the dramatic differences in Supreme Court views of the Clean Water Act's breadth depending on permit context illuminates a structural weakness in the Act overall: Despite the fact that Congress initially conceived the two permit programs as performing very different functions, it yoked them together interpretatively through a single statutory trigger and set of definitions. Rather than continuing the frustrating efforts to draft a single set of "waters of the United States" regulations that serve both regulatory programs, water quality would benefit tremendously from a complete separation of the two programs. The Supreme Court may have created enough of an interpretive loophole that would allow the EPA and Army Corps to achieve this separation themselves, ${ }^{408}$ but a congressional amendment would be cleaner and less susceptible to ongoing litigation. As a bonus, clear separation of the two permit programs could also prove a boon to building political momentum to finally extend the Clean Water Act to the NPDES-like water pollution that agricultural createsreturn flows from irrigation and channelized agricultural stormwater, long exempt from regulation ${ }^{409}$ - without even the hint of a threat to farmers' day-to-day activities, which has formed the basis of the American Farm Bureau's strong (if not always legally accurate) opposition to the "waters of the United States" regulations. ${ }^{410}$

\section{CONCLUSION}

Protecting ourselves from ourselves is one of the trickiest purposes of public law. Nevertheless, in numerous contexts, generational amnesia has allowed the public, courts, regulatory agencies, politicians, and legislatures to embrace the regulatory shifting baseline syndrome, allowing history to repeat itself.

If one accepts that the shifting baseline syndrome is a real phenomenon with real consequences that generally impoverish society as a whole-whether through a degraded natural resource base, loss of global economic stability, or increased threats to public health - the question then becomes how to prevent, or at least correct for, its emergence. The loss of intergeneration memory about historical ecological conditions_- "environmental generational amnesia"411_may require active reconstruction of cultural memory through new sources of data and creative extrapolation. For the regulatory shifting baseline syndrome, however, the cultural

\footnotetext{
${ }^{408}$ In a series of cases, the Court has held that identical language does not have to mean the same thing in different parts of a statute. E.g., Environmental Defense v. Duke Energy Corp., 549 U.S. 561, 574-76 (2007).

40933 U.S.C. $§ 1362(14)$.

410 Clean Water Act, WOTUS, Amer. FARM Bureau (viewed Feb. 23, 2021), https://www.fb.org/issues/regulatory-reform/clean-water-act/.

${ }^{411}$ Kahn, supra note 52, at 93-94.
} 
memory is right there-embodied in the very regulatory regime whose success allows the syndrome to emerge.

More information, in other words, is unlikely to be a necessary or effective corrective to the regulatory shifting baseline syndrome. Instead, the various regulatory gatekeepers - members of legislatures, agency personnel, presidents and governors, and judges - need institutional prods to remind them to remember and to value the cultural memory they retrieve. For constitutional and other reasons, these institutional prods will largely need to function as norms rather than as requirements. Nevertheless, institutional norms, once developed, can still be powerful. As one example, when FDR broke the two-term presidential norm that George Washington established, the result was a constitutional amendment to ensure that no President ever did it again. ${ }^{412}$

The first step in correcting the regulatory shifting baseline syndrome is deceptively simple: A broad swath of society must identify regulatory regimes as memory institutions. When interest groups or even a large percentage of the population challenge a longstanding public regulatory regime as outdated and obstructionist, the first response should become: "Why does it exist in the first place? What problem might we resurrect if this regime goes away?"

Again, the point is not that longstanding public regulatory regimes cannot outlive their usefulness; they most certainly can. The point, rather, is that legislatures and agencies created them for a reason-a reason that was worth the effort and expense of putting the new regime into place. Particularly when the industries and interest groups that propose dismantling the regime argue in favor of the private benefits that will result-more profit, greater property rights, even (in the right circumstances) greater individual freedom and states' rights - a high threshold of skepticism and a presumption in favor of continuing to protect the general public welfare is warranted.

The second step is to reconstitute the full risk-benefit balancing at issue. At the very least, regulatory gatekeepers should understand the full range of societal problems at stake before they attempt to re-evaluate the regulatory regime for contemporary circumstances. The temptation in light of immediate political pressure is to discount the vanquished regulatory problem as irrelevant - to shift the regulatory baseline. Therefore, to ensure that this impulse is not in fact the regulatory shifting baseline syndrome, legislatures and courts should assess the extent to which the public is still benefitting from the regulatory regime-even if the problem itself has not been seen for decades. Will certain states create discriminatory voting regimes in the absence of federal oversight? Both historical and contemporary evidence clearly indicate that they will. Will the economy crash again if we let the financial industries do what they want? All available evidence says yes. Will infectious diseases return to the United States if we stop vaccinating and allow herd immunity to lapse? Again, with the exception of completely or geographically eradicated diseases like smallpox and polio, all available evidence

${ }^{412}$ U.S. Const., amend. 22 (passed by Congress March 21, 1947, ratified Feb. 27, 1951). 
says yes. Will industries protect waterways in the absence of effective regulation? History says no.

We should listen to history. 